IZA DP No. 7069

Income, Democracy, and Critical Junctures

Matteo Cervellati

Florian Jung

Uwe Sunde

Thomas Vischer

December 2012 


\title{
Income, Democracy, and Critical Junctures
}

\author{
Matteo Cervellati \\ University of Bologna and IZA
}

\author{
Florian Jung \\ University of St.Gallen
}

Uwe Sunde

LMU Munich, IZA and CEPR

\author{
Thomas Vischer \\ LMU Munich
}

\section{Discussion Paper No. 7069 \\ December 2012}

\author{
IZA \\ P.O. Box 7240 \\ 53072 Bonn \\ Germany \\ Phone: +49-228-3894-0 \\ Fax: +49-228-3894-180 \\ E-mail: iza@iza.org
}

Any opinions expressed here are those of the author(s) and not those of IZA. Research published in this series may include views on policy, but the institute itself takes no institutional policy positions. The IZA research network is committed to the IZA Guiding Principles of Research Integrity.

The Institute for the Study of Labor (IZA) in Bonn is a local and virtual international research center and a place of communication between science, politics and business. IZA is an independent nonprofit organization supported by Deutsche Post Foundation. The center is associated with the University of Bonn and offers a stimulating research environment through its international network, workshops and conferences, data service, project support, research visits and doctoral program. IZA engages in (i) original and internationally competitive research in all fields of labor economics, (ii) development of policy concepts, and (iii) dissemination of research results and concepts to the interested public.

IZA Discussion Papers often represent preliminary work and are circulated to encourage discussion. Citation of such a paper should account for its provisional character. A revised version may be available directly from the author. 
IZA Discussion Paper No. 7069

December 2012

\section{ABSTRACT}

\section{Income, Democracy, and Critical Junctures}

Acemoglu, Johnson, Robinson, and Yared (2008) document that the cross-country correlation between income per capita and democracy disappears once including country fixed effects. This paper tests the hypothesis that the effect of income on democracy might differ systematically across countries. A replication of the estimation in a less restrictive empirical framework provides evidence for significant but heterogeneous effects of income on democracy for former colonies and non-colonies, as well as within the sample of former colonies. These heterogeneous effects are related to colonial history and early institutions, and are robust to the use of alternative data and estimation techniques.

JEL Classification: $\quad \mathrm{P} 16, \mathrm{O} 10$

Keywords: critical junctures, democracy, economic development, income, institutions, modernization hypothesis

Corresponding author:

Uwe Sunde

Ludwig-Maximilians-Universität

Seminar für Bevölkerungsökonomie

Schackstr. 4/IV Stock, Raum 413

80539 München

Germany

E-mail: uwe.sunde@econ.Imu.de

\footnotetext{
* The authors wish to thank Daron Acemoglu, Carl-Johan Dalgaard, Frank Windmeijer and seminar participants at the University of St.Gallen and the Zeuthen-Workshop 2012 in Copenhagen for comments and suggestions.
} 


\section{Introduction}

In a widely cited and highly influential article, Daron Acemoglu, Simon Johnson, James Robinson and Pierre Yared (2008), henceforth AJRY (2008), revisit the relationship between income per capita and democracy. Previous investigations using cross-country variation had found a strong positive statistical association between income and democracy, which was generally interpreted as evidence in favor of Lipset's (1959) "Modernization Hypothesis". AJRY (2008) estimate the relationship by exploiting within-country variation over time. The main result of the empirical analysis of AJRY (2008) is that the positive association between income and democracy vanishes in data for the postwar period, 1960 to 2000, once country and time fixed effects are explicitly accounted for. Their rather precise point estimate of zero for the effect of income on democracy is robust to an extensive set of robustness checks.

The main hypothesis underlying their analysis is that cross-country correlations might conceal important systematic differences across countries that affect development in both incomes and democracy. The inclusion of country fixed effects accounts for potential omitted variable bias due to the existence of country-specific historical (third) factors that affect both political and economic development. Such country-specific factors include relevant and persistent country characteristics, most notably institutions, that emerge as the result of historical contingencies at certain critical junctures. As consequence, countries "embark on divergent political and economic development paths, some leading to relative prosperity and democracy, others to relative poverty and dictatorship" (AJRY, 2008, p. 812). According to AJRY (2008), a prime example for such a critical juncture is the colonization history of a country. Their results provide support for this view by showing that the association between income and democracy is substantially weakened once accounting for a country's colonial history (in terms of, e.g., the year of independence) or for proxies for early institutions like the constraints on the executive in 1900, instead of country fixed effects. In addition, they also argue that a critical juncture for the group of former colonies "corresponds to the experience under the European colonization" (AJRY, 2008, p. 813) 1]

This paper revisits the analysis of AJRY (2008), starting from the observation that in view of the literature one should expect income changes to have a heterogenous effect on changes in democracy

\footnotetext{
${ }^{1}$ The critical role of colonial strategies and history dependence for the emergence and persistence of institutions in former European colonies has been investigated previously by Acemoglu, Johnson, and Robinson (2001, 2002). The available evidence indicates that the emerging institutions varied substantially depending on the possibilities for rent extraction and on the suitability for permanent colonial settlements, see AJRY, (2008, p. 813) as well as AJRY (2009, p. 1045) and Acemoglu and Robinson (2012) for an extensive discussion of literature and the available evidence.
} 
depending on a country's colonial history and institutions. Already Lipset (1959) argued that the positive role of economic development for political legitimacy (i.e., the "Modernization Hypothesis") can be expected to hold mainly for "free" societies 2 A positive effect of income on democracy should therefore not be taken as an unconditional prediction that pertains to all countries, but this effect should rather be expected to emerge in countries with more inclusive institutions. The main alternative hypothesis to the modernization theory, the "window of opportunity" put forward by Acemoglu and Robinson (2006), predicts a negative relationship: reductions (and not increases) in income may improve the prospects of democracy by reducing the opportunity cost of uprise against the ruling autocratic elites $3^{3}$ Taken together, these arguments suggest that a positive relationship between changes in income and changes in democracy should be more likely in countries with more inclusive, or free, institutions while a negative relationship should be more likely in countries with more extractive institutions.

The empirical analysis of AJRY (2008) is based on an extension of the cross-sectional linear regression framework to the inclusion of country and (common) time fixed effects. The empirical validity of the linear framework rests on the assumption that the effect of income on democracy is homogenous for all countries in the sample. The model is correctly specified to estimate the income effect on democracy if the relevant (time invariant) country-specific heterogeneity (e.g., colonial history or institutions) affects democracy only in terms of the (average) variation in democracy (that is, the different intercepts of the regression line as picked up by the country fixed effects), but not in terms of the effect of changes of income on changes of democracy (that is, in terms of the slope of

\footnotetext{
${ }^{2}$ Lipset (1959) restricted attention to self-governing states by noting that other historical events, especially those restraining the independence of countries through the influence of third parties, might interfere with the relationship between income and democracy. In their base sample, AJRY (2008) restrict attention to the post-independence period to make their test as close as possible to Lipset's argument. The heterogeneity in institutions within colonies is likely to be persistent in time even after independence, however. For instance, as pointed out by Brown (1999) (p. 710) “... many successor nations continued to be ruled in essentially colonial ways, enabling established leaderships to maintain a type of domestic neo-colonialism".

${ }^{3}$ This hypothesis applies particularly to episodes of democratization in extractive societies, such as former colonies, where the ruling elites are more reluctant to give away their political power peacefully. Elites may actually get stronger and more repressive following an increase in income in these countries. See Lipset (1959) and Huntington (1991) for related arguments. A higher likelihood of a "window of opportunity" effect in colonies is also indirectly supported by a considerable empirical literature in political science and economics. For instance, Bernhard et al. (2004), discuss a number of studies that "argue that colonial economic development distorted the social structure in ways that (a) increased the power of classes that have been resistant to democracy while (b) weakening those classes whose struggles for political influence and incorporation have been historically associated with the establishment of democracy."
} 
the income effect). Whether this is indeed the case is essentially an empirical question.

The analysis in this paper follows closely the hypothesis discussed above and tests whether a specification that assumes a homogeneous effect of income is valid, or whether the effect is indeed heterogenous depending on (colonial) history or institutions. The analysis proceeds in two steps. First, we investigate if the effect of income on democracy is heterogenous depending on whether a country has ever been subject to foreign rule (that is, whether it is a former colony), or not. Second, we investigate if the effect of income on democracy is heterogenous within the sample of colonies, depending on the historical contingencies of a country (e.g., the date of independence, or the colonizer), or the early institutions in a country (e.g., the constraint on the executive in 1900).

The results reveal substantial heterogeneity in the income effect on democracy across former colonies and non-colonies. In line with the hypothesis discussed above, the effect of income on democracy is negative in former colonies but positive in countries that have never been colonized. Within colonies, the effect of income is also heterogenous and (even) more negative in countries that were subject to more extractive colonization strategies and that historically displayed lower constraints on the executive. These findings are confirmed by extensive robustness checks. The results consistently hold up when using alternative data on democracy, income, colony codings and data frequencies $4^{4}$ The heterogenous effect of income on democracy is not confined to the use of fixed effects regressions and consistently emerges using alternative empirical strategies that are available to account for potential biases. These include, in particular, the robustness checks by AJRY (2008) like the use of GMM estimators, IV strategies and GMM-IV $5^{5}$ The heterogeneity in the income effect within the sample of former colonies is found also with alternative data on colonial history and institutions, while no interactions with other variables are found to be relevant ${ }^{6}$ Finally, the results

\footnotetext{
${ }^{4}$ For direct comparability to AJRY (2008), we use the data from the Freedom House for democracy, from the PWT 6.1 for income, and the CEPII colony coding (that includes information for all countries in the baseline sample) as benchmark. The results consistently emerge for alternative codings of democracy like the Polity IV index or binary measures of democracy, alternative income data by using the latest data release, PWT 7.1, and alternative codings of colonies, including the colony coding used by AJRY (2008) that contains information only for a subset of the countries in their data set, as well as a coding from the Quality of Governance Dataset that classifies Western off-shoots as non-colonies. The data sources are discussed in more detail in Section 2, The whole analysis is conducted at both five-year and ten-year panel data frequencies.

${ }^{5}$ The results are robust to alternative estimation methods that have been proposed in the subsequent literature, including the use of Tobit models and other bias-corrected estimators.

${ }^{6}$ For the colony sample, we consider the constraints on the executive, the date of independence and the type of colonizer as benchmark proxies for colonial history and early institutions, following AJRY (2008, 2009). The results are also confirmed when using alternative proxies like the share of the population with European descent,
} 
are robust to the consideration of potential heterogeneity of the income effect for transitions to and away from democracy that was considered in a companion paper by AJRY (2009), the consideration of different samples (excluding e.g. socialist, Muslim and oil countries) and the inclusion of additional covariates (like education and population controls).

The results of this paper substantially qualify the existing evidence in several dimensions. First, the analysis is conducted by relaxing the assumption of a homogeneous effect of income on democracy to test the existence of heterogeneous effects. Thereby, the empirical analysis nests the linear empirical framework with a homogeneous income effect used by AJRY (2008) as a special case, which is obtained if the effect of income on democracy is not heterogeneous across countries. The empirical results reject the null hypothesis that the restriction of a homogeneous effect is valid. The effect of income on democracy is opposite in sign for colonies and non-colonies (negative for colonies and positive for non-colonies), significantly different from zero (which is the point estimate obtained when constraining the effect to be homogeneous), and relevant in magnitude.

Second, the existence of a heterogenous effect of income also implies that the results obtained with a linear framework (and in particular the existence of a zero effect) are not robust to sample composition. In fact, the heterogeneity in the income effect documented in this paper implies that the results obtained with linear regressions can be misleading since the point estimates can range from significantly positive to significantly negative, depending on the countries that are included in the sample.7

A third relevant contribution of this paper is a systematic investigation of the existence of a heterogenous effect that follows from the hypotheses in the literature. The empirical strategy is designed to test the prediction of a heterogeneous effect of income on democracy depending on a country's colonial history and the quality of early institutions 8 The analysis highlights an aspect of history and institutions that appears crucial but more subtle than previously thought, in a way that has not been pointed out in the existing literature.

the date of colonization, or the religious fractionalization (which may be informative on divide-and-rule colonization strategies). We do not find evidence for relevant interactions of income with other time invariant variables that should not represent relevant proxies for broad-based institutions that emerged during the colonial history in view of the hypothesis discussed above. These variables include geographical features like the share of land in the tropics, an Africa dummy, or the share of arable land.

${ }^{7}$ This effect of sample composition can contribute to explaining the mixed findings that have been reported in the recent literature that replicates AJRY (2008) using alternative estimation techniques and samples, but maintaining the assumption of a homogeneous effect of income on democracy.

${ }^{8}$ It should be noted that the analysis in this paper is not implemented as a purely statistical search for heterogenous effects, which may lead to results that can be hard to interpret and validate with further checks. 
This paper is structured as follows. Section 2 describes the econometric specification and the data. Section 3 presents the results.

\section{Data and Empirical Specification}

\subsection{Data}

The baseline analysis draws on the cross-country panel data compiled by AJRY (2008).9 $9^{9}$ The estimation is based on five-year and ten-year panel data sets over the period 1960-2000 ${ }^{10}$ As benchmark index of democracy we use the data provided by Freedom House. The index is normalized to the range between zero and one, with higher values indicating higher levels of democracy ${ }^{11}$ The primary source for data on GDP per capita is the Penn World Tables ${ }^{12}$

As a benchmark information on whether a country was a former colony we use information from the French Center for Research and Studies on the World Economy (CEPII) database, which has the advantage of providing a complete classification of colonial status of all countries in the sample 13 The second part of the analysis exploits heterogeneity in the colonial history of former colonies. In

\footnotetext{
${ }^{9}$ The data are available at http://pubs . aeaweb.org/doi/pdfplus/10.1257/aer .98.3.808.

${ }^{10}$ The analysis concentrates on the time after 1960 because of serious data limitations for former colonies before 1960. Data are only available for very few colonies before 1960, and the sample becomes increasingly biased towards particular groups of colonies when going back in time, which renders it inappropriate for the purposes of this study. In addition, a comparison of former colonies and non-colonies becomes increasingly problematic for the period before 1960 due to the ongoing colonial domination in many countries in this period. See also the discussion in AJRY (2008) about the inconsistency of the fixed effects estimator when the critical juncture occurs during the observation period.

${ }^{11}$ As alternative measure for democracy, we consider the Polity IV index, which is normalized to the range between zero and one. For robustness, the analysis is also conducted with binary indicators of democracy, see Section 3.4 for details.

${ }^{12}$ For direct comparability we use the release PWT6.1 as benchmark and other income data (including in particular the latest available release PWT7.1) for robustness checks.

${ }^{13}$ Following the earlier literature including Acemoglu et al. (2001, 2002), the empirical analysis focuses exclusively on Western overseas colonialism. The source for the CEPII data is http://www.cepii.fr/. This data set includes all countries in the baseline sample of AJRY (2008), who also report information on former colonial status, but only for a subset of countries that is included in their 500-year panel. As consequence, some countries, in particular those that lack GDP data for time periods before the fall of the Soviet Union, are not coded with respect to colonial history. The two classifications are, however, very similar. In contrast to the colony coding in the AJRY (2008) data, the CEPII coding provides information on the respective (last) colonizing power of a former colony. The entire analysis is replicated using both colony codings as well as for a third coding that is available from the Quality of Governance institute (QoG data set; see http://www.qog.pol.gu.se/). This coding treats Western offshoots (Australia, Canada, New Zealand and the U.S.) as non-colonies.
} 
particular, we use data on constraints on the executive in 1900 taken from Acemoglu, Johnson, and Robinson (2002), the year of independence as well information on the most recent colonial power taken from the CIA World Fact Book and from CEPII 14

\subsection{Econometric Specification}

As benchmark we adopt the specification of the empirical model as in AJRY (2008),

$$
d_{i, t}=\alpha d_{i, t-1}+\gamma y_{i, t-1}+\delta_{i}+\mu_{t}+u_{i, t}
$$

where $d_{i, t}$ is the democracy score of country $i$ at time $t$. This specification implies that the empirical model is dynamic as it captures persistence as well as mean-reverting dynamics by including the influence of the lagged value of the dependent variable $d_{i, t-1}$ in terms of the coefficient $\alpha$. The coefficient of main interest is $\gamma$ and reflects the effect of the lagged value of log income per capita $y_{i, t-1}$ on democracy. The specification includes a full set of country fixed effects $\delta_{i}$ and time dummies $\mu_{t} 15$ Additional transitory shocks to democracy and other omitted factors are captured in the error term $u_{i, t}$.

To account for heterogeneous effects of income on democracy, the model (1) can be extended by allowing income per capita to have different effects on democracy in different groups of countries, by considering the (partially) interacted model,

$$
d_{i, t}=\alpha d_{i, t-1}+\gamma y_{i, t-1}+\phi\left(y_{i, t-1} \cdot c_{i}\right)+\delta_{i}+\mu_{t}+u_{i, t},
$$

where the variable $c_{i}$ denotes a time invariant country specific feature. In section 3.2 , we estimate the model (2) with $c_{i}$ indicating whether a country is a former colony or not. The empirical model (1), which has been estimated by AJRY (2008), is nested in model (2). Both models exactly coincide if $\phi=0$, that is, if the effect of income on democracy does not depend on the variable $c_{i}$, which allows for testing the validity of the extension to heterogeneous effects of income on democracy under the null hypothesis that $\phi=0 .{ }^{16}$ The partially interacted model (2) allows for an efficient test by exploiting variation in the full sample and allowing the effect of income to be heterogenous across countries with different institutional features, $c_{i}$, while maintaining the assumption that all other coefficients are the same across all countries. This assumption is not necessarily justified across the different sub-samples, however. Estimating a fully interacted model, i.e., estimating the empirical model (1)

\footnotetext{
${ }^{14}$ Additional data on country specific characteristic used for robustness are taken from Alesina et al. (2003), Olsson (2009), Putterman and Weil (2010) and Ashraf and Galor (2011).

${ }^{15} \mathrm{As}$ in AJRY (2008), we also include additional covariates in terms of a vector $x_{i, t-1}^{\prime} \beta$ in some specifications.

${ }^{16}$ Notice that the fact that proxies for long-run institutions are time invariant implies that the main effect of $c_{i}$ in specification (2) is already subsumed in the country fixed effect.
} 
separately for the different groups of countries, is a more flexible but less efficient strategy, since it allows for the possibility of heterogeneous convergence processes and development dynamics (in terms of coefficients $\alpha$ and $\delta$ ), but it involves estimating a substantially larger number of parameters. In section 3.2 we also explore the existence of heterogenous effect of income on democracy in non colonies and colonies by estimating the empirical model (1) for the two sub-samples of former colonies and non-colonies. The results for the sample of colonies can be used as benchmark to investigate the existence of further heterogenous effects within the sample of former colonies using the empirical model (2), which is done in Section 3.3. In this analysis, $c_{i}$ represents an indicator that proxies the heterogeneity in institutional features across colonies ${ }^{17}$

\section{Income and Democracy: Empirical Results}

\subsection{Preliminary Evidence}

The typical finding in the literature is a positive effect of income on democracy when exploiting cross-sectional variation 18 Figure 1 (a) provides a graphical illustration of this finding by plotting the effect of lagged GDP per capita on democracy as measured by the Freedom House index, net of past democracy and year fixed effects in a cross-country panel over the period 1960-2000 with 5-year frequency. The slope of the regression line represents the effect of income on democracy as obtained from estimating the empirical model (1) without country fixed effects. As, discussed above, a crucial contribution of AJRY (2008) is to document that the effect of income on democracy disappears once time invariant country-specific factors, which also reflect the history of these countries, are included in the estimation framework. Figure 1 (b) shows this by plotting the respective correlation when exploiting within-country variation in the data 19 Income per capita does not appear to be related to democracy once country fixed effects are included.

This paper explores the hypothesis that the effect of income on democracy might differ system-

\footnotetext{
${ }^{17}$ Also for the sub-sample of colonies the variable $c_{i}$ is not relevant for the effect of income on democracy under the null hypothesis, implying that the results of the two models coincide.

${ }^{18}$ The modernization hypothesis has been assessed empirically in numerous studies, see Bollen and Jackman (1985), Arat (1988), Diamond (1992), Burkhart and Lewis-Beck (1994), Barro (1999, 2012), Przeworski et al. (2000), Boix and Stokes (2003), Glaeser et al. (2004), Epstein et al. (2006), and Przeworski et al. (2006), as the most prominent examples, see also Cheibub and Vreeland (2010) for a recent survey.

${ }^{19}$ The graph depicts the predicted effect of income on democracy, net of past democracy, year fixed effects and country fixed effects in a cross-country panel 1960-2000 with 5-year frequency. This is the effect that is obtained estimating the empirical model $\sqrt{1}$ in the full sample. Corresponding estimation results are reported in Table 1 below.
} 


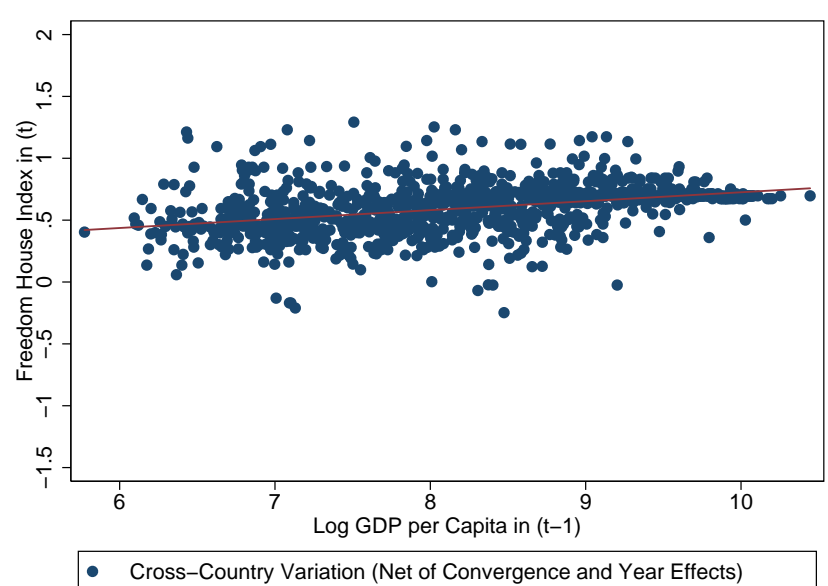

(a) Cross-Country Variation, Full Sample

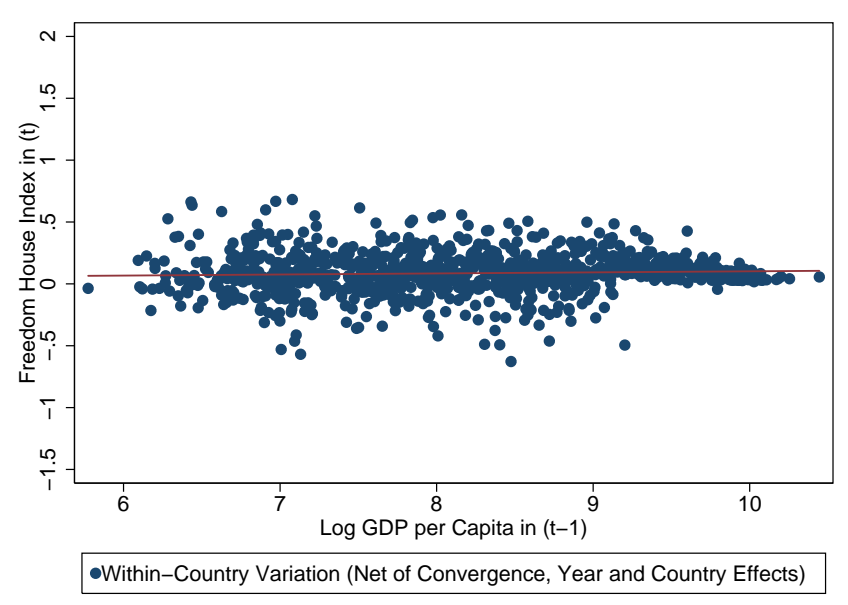

(b) Within-Country Variation, Full Sample

Figure 1: The Effect of Income on Democracy

atically across countries with different colonial history and institutional backgrounds. Figure 2(a) provides a graphical illustration of the results obtained by estimating a model that accounts for country fixed effects, but that allows for heterogeneous effects in former colonies and non-colonies in terms of a separate estimation of specification (1) for the sub-samples of former colonies and non-colonies, respectively ${ }^{20}$ Figure 2 (b) shows the results from the same estimates of a specification (1) for the sample of non-colonies and colonies, but where the income effect is allowed to differ across former colonies without and with constraints on the executive in 1900 ${ }^{21}$ These figures suggest that there is substantial heterogeneity in the effect of income on democracy across non-colonies and former colonies, as well as among colonies for countries with and without inclusive institutions in terms of early constraints on the executive. In particular, the slope of the income-democracy nexus appears to differ in sub-samples that differ in terms of their broad institutional background, consistent with the hypothesis of a heterogeneous effect of income on democracy. The following analysis provides a systematic investigation of these patterns.

\subsection{The Effect of Income in Non Colonies and Colonies}

Fixed Effects Regressions. Table 1 presents the results from estimating model (1) with data from the entire sample of countries over the period 1960 to 2000 using the Freedom House measure

\footnotetext{
${ }^{20}$ The estimation corresponds to a fully interacted model that allows all coefficients to differ between non-colonies and colonies. The estimation of a partially interacted model (2) delivers similar results.

${ }^{21}$ This corresponds to estimating a model $(2)$ for the sample of former colonies. A similar figure obtains when splitting colonies depending on whether a colony became independent before 1900 or after.
} 

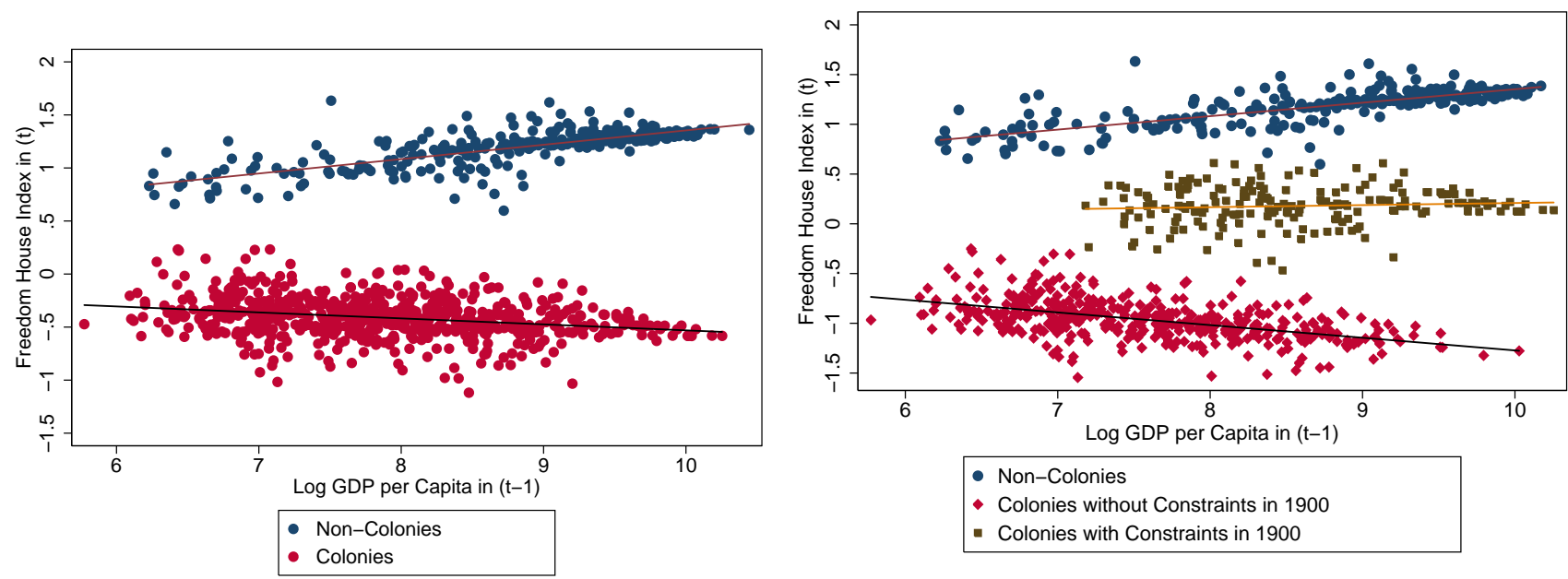

(a) Within-Country Variation, Non-Colonies and (b) Within-Country Variation, Non-Colonies and Colonies Colonies

With and Without Constraints on the Executive 1900

Figure 2: Heterogeneous Effects of Income on Democracy

of democracy. Column (1) replicates the results of AJRY (2008) using their data, sample and specification in the five-year panel in terms of a rather precise estimate of a zero effect of log income per capita (in period $t-1$ ) on democracy (in period $t$ ). Past democracy, on the other hand, has a highly significant effect on present democracy. Column (3) presents the same result for the ten-year panel. In this specification, income has no significant effect on democracy, and even the significant effect of past democracy vanishes.

As a first step in the investigation of the potentially heterogenous effect of income on democracy in countries with different colonial history and institutional background, columns (2) and (4) of Table 1, report the results from estimating the model (2), where $c_{i}$ is a binary indicator variable that takes value 1 if a country is a former colony, and 0 if a country has never been colonized (using the colony coding in the CEPII data). Recall that the empirical specification (2) nests the baseline specification of AJRY (2008) as a special case (which is obtained if the effect of income on democracy is homogenous). The findings reject the null hypothesis of a homogenous effect of income across those countries that were, and those that were not, subject to foreign colonial rule. The results document a significant and positive effect of income on democracy for non-colonies and a significant negative interaction effect for colonies. The negative interaction effect is even larger in size than the main effect, suggesting that income indeed affects democracy significantly positively in countries that have never been colonized, whereas the effect is negative (but statistically insignificant) for former 
colonies ${ }^{22}$ This finding is robust to the use of the ten-year panel frequency, but the point estimates are approximately twice as large when considering the ten year panel, see column (4).

Table 2 presents the results from estimating the empirical model (1) separately for the samples of former colonies and non-colonies. Panel A shows the results for the sub-sample of countries that had never been subject to foreign colonial rule, Panel B shows the results for former colonies. Column (1) contains the estimation results obtained with the full sample using all available data for the two groups of countries. Since the time series may contain missing information on specific time periods, Column (2) replicates the analysis by restricting attention to quasi-balanced panels that include only countries for which the relevant data are observed for at least six periods and which therefore exhibit a reasonably long time series dimension. Finally, Column (3) presents results for fully balanced panels of countries, which represent the most restrictive samples ${ }^{23}$

The estimation results confirm the findings: income has a significant positive effect on democracy in countries that have never been colonized (Panel A). In contrast to that, the results show a significant negative effect of income on democracies in former colonies (Panel B). This also implies that the effects are significantly different from each other for non-colonies and colonies. These results emerge regardless of whether one looks at the full sample or more restricted samples.

The pattern also emerges consistently for the ten-year panels, reported in Columns (4), (5) and (6). In the ten-year panel, there is little evidence of persistence in democracy for either group of countries, and the effect of income on democracy (positive in the sample of non-colonies and negative in the sample of colonies) is larger in terms of absolute magnitude, consistent with the baseline results of Table $1{ }^{24}$

The results also document significantly different effects of past democracy on current democracy in the two sub-samples, suggesting that the partially interacted model is overly restrictive ${ }^{25}$ In both cases, past democracy has a positive effect on current democracy, but the persistence in democratic quality is substantially larger in non-colonies than in colonies in the five-year panel, which provides additional evidence for heterogeneous development patterns in colonies and non-colonies that is reflected in different persistence of democracy.

\footnotetext{
${ }^{22}$ Notice that the total effect of income on democracy for former colonies is given by the sum of the coefficients on the income variable and on the interaction variable.

${ }^{23}$ The fully balanced sample restriction is identical to that made by AJRY (2008).

${ }^{24}$ As discussed in section 3.4 below, these effects are not only statistically but also quantitatively relevant.

${ }^{25}$ The results also reveal significant differences in the dynamics, reflected by period dummies, $\delta_{t}$, across former colonies and non-colonies. Details are available upon request.
} 
Alternative Estimation Methods. Due to the inclusion of the lagged dependent variable in a fixed effects framework, the estimates of the effect of income on democracy are potentially biased (Nickell, 1981). This problem can be particularly relevant if the number of time-series observations is small. This bias is unlikely to be the driving factor behind the finding of a heterogenous effect in non colonies and colonies, however, since there is no reason why this statistical bias should be consistently different in different samples of countries, and hence drive the finding of a heterogeneous effect of income on democracy. Nevertheless, we apply alternative estimation methods, including the ones that have been adopted by AJRY (2008), to mitigate potential concerns regarding biased estimates in dynamic panels with fixed effects.

A first strategy involves using GMM estimators along the line of AJRY (2008). The corresponding estimates are consistent although they critically depend on the identification assumptions and the strength of past levels as instruments for the change in democracy ${ }^{26}$ The properties of the GMM estimator require the cross-section dimension of the panel to be sufficiently large. A small crosssection dimension imposes constraints on the number of instruments that can effectively be used (see Roodman, 2009). To limit problems of instrument proliferation, we follow the best practice of adopting parsimonious specifications that pass the usual specification tests using the minimal number of instruments. ${ }^{27}$ Columns (7) and (8) of Table 2 present the respective GMM results. The main result that the income effect is positive for the sample of non-colonies but negative for the sample of colonies is confirmed. In particular, the estimates for the persistence term $\alpha$ are similar to those obtained with fixed effects, while the heterogeneity of the income effect is slightly more pronounced in the GMM estimates 28

\footnotetext{
${ }^{26}$ AJRY (2008) estimate difference GMM models along Arellano and Bond (1991), but refrain from using systemGMM estimation methods along the lines of Arellano and Bover (1995) or Blundell and Bond (1998), because the time-differenced instruments that are used for the level equation in the system estimation are unlikely to be orthogonal to the country fixed effects. For this to be satisfied (and the estimator to be valid), it is effectively required that all countries are in steady state, which is not the case. In fact, while we still obtain evidence for a heterogenous income effect on democracy when estimating system GMM models, the specification tests reject the validity of the additional instruments in these models.

${ }^{27}$ If the number of instruments is too large, the estimator may fail to expunge the endogenous component of the instrumented regressor. A rule of thumb for the maximal number of instruments is conventionally taken to be the number of cross-sectional units, see Roodman (2009a, 2009b). The specifications shown here make use of two and three lags of democracy as instruments, which keeps the number of instruments sufficiently small (see also the table notes for details).

${ }^{28}$ As an alternative for fixed effects regressions with lagged dependent variable in small panels, Bruno (2005) proposed a biased corrected least squares dummy variable (LSDVC) estimator, which is also appropriate for unbalanced panels with a small cross-sectional dimension. The results obtained with this estimator confirm the finding of a heterogeneous
} 
AJRY (2008) also present instrumental variables estimates that rely on exogenous sources of variation and thus account for potential concerns about reverse causality. Their main instrumentation strategy exploits trade linkages across countries that induce the transmission of variations in income from the rest of the world to a particular country under consideration ${ }^{29}$ Column (9) of Table 2 presents the results of the outcome equation when instrumenting lagged income per capita using the trade weighted world income instrument. The instrument is weak in terms of first stage performance for the set of non-colonies and the estimates of the effects in the outcome equation are therefore not reliable 30 For the sample of former colonies the instrument works well, with an F-statistic substantially exceeding the conventional critical value. The IV results confirm the earlier findings with a negative and significant effect of income on democracy in the sample of former colonies. Finally, column (10) of Table 2 presents the results of GMM estimations when instrumenting lagged income using the trade weighted world income instrument. Again the results for the non-colonies essentially collapse to the findings obtained without instrumentation. The instrumentation works better for the colony sample. The findings confirm that the effect of income on democracy is negative, and slightly stronger in magnitude compared to the OLS estimates. In terms of the size of the effects, GMM and IV methods deliver slightly larger coefficient estimates in absolute terms. This suggests that, if anything, the fixed effects estimates reveal lower heterogeneity across colonies and non-colonies than what is found using these more refined estimation methods.

\subsection{The Effect of Income on Democracy within Colonies}

The hypothesis of a heterogeneous effect of income on democracy is not confined to the consideration of former colonies and non-colonies. In fact, as discussed in Section 1, the arguments made by AJRY (2008) and in the literature suggest that colonial history and the institutions that emerged in the

effect across non-colonies and colonies and are available upon request.

${ }^{29}$ The trade-weighted level of income in the rest of the world should therefore be a suitable instrument for the income in a particular country, since it affects the level of income through the transmission channel, while being plausibly exogenous to the level of democracy in the country conditional on the other controls. AJRY (2008) also consider lagged savings rates as a further instrument for income changes even though they point out that there is no strong reason to believe that this variable satisfies the conditions for an instrument, which is why we focus attention on the world income instrument as benchmark. Results with the savings instrument are qualitatively similar although the instrument does not perform as well as the trade-weighted income. These further results are available upon request.

${ }^{30}$ Additional unreported results that were obtained for a reduced sample that drops all country-year observations with a democracy index of 1 (censored observations) delivers a considerably stronger first stage performance of the instrument with an $\mathrm{F}$ of 24 and a positive income effect of 0.281 [s.e. 0.161] on the second stage. 
context of colonization should be a relevant critical juncture and should matter for the effect of income on democracy. It is therefore natural to investigate whether there is heterogeneity in the effect of income on democracy within the sample of former colonies.

This section presents the results of the estimation of empirical models as in (2), which allow for the possibility that the effect of income on democracies is heterogenous within colonies, using different proxies for institutional quality that have been suggested by AJRY (2008). As a first proxy for the (historical) institutions we use the level of constraints on the executive in 1900. For comparability to the results reported in Table 2, and to facilitate the interpretation of the quantitative effects, we consider a dummy variable $c_{i}$ that takes value 0 if a country had no constraints on the executive in 1900 and value 1 if the country had some constraints. This coding follows that of AJRY (2008). As before, the specification nests the linear model (1) as a special case. Under the null hypothesis that different constraints on the executive in 1900 do not matter for the effect of income on democracy after 1960, the estimates should coincide with those reported in Panel B of Table 2.

Table 3 presents the respective results for 5-year and 10-year panel data. The findings document a significant heterogeneity in the effect of income on democracy in colonies, depending on the constraints on the executive in 1900. In particular, in countries with no constraints the negative effect of income on democracy is significantly negative and about twice as large as the respective average effect documented in Table 2. Compared to this, the effect of income is significantly more positive in countries with some constraints on the executive in 1900 (as reflected by the positive coefficient for the interaction term), with the total effect of income on democracy being essentially zero 31 Columns (3) and (4) show that the same pattern emerges also in GMM estimates, with the coefficient estimates being absolutely larger than the respective results of Table 2 .

As alternative proxies for institutional quality, we follow AJRY (2008) and consider the year of independence as "another measure of colonization strategy, since non-extractive colonies gained their independence typically earlier than the extractive ones" (Acemoglu et al., 2009, p. 1046). Columns (5) - (8) of Table 3 present the results when proxying institutional quality by a binary indicator variable, $c_{i}$, that takes value 1 if a country became independent before 1900232 The results

\footnotetext{
${ }^{31}$ Recall that in this specification the total effect of income for countries with some constraint on the executive is given by the sum of the coefficients on the income variable and on the interaction variable.

${ }^{32}$ This reasoning, according to which settler colonies became independent earlier than colonies that were set up for exploitation follows AJRY (2008) and is also supported by the political science literature, see Rueschemeyer, Huber Stephens, and Stephens (1992), Lipset, Seong, and Torres (1993), or Bernhard, Reenock, and Nordstrom (2004), and by recent findings of Bertocchi and Guerzoni (2010) who analyze the causes of state fragility in SubSaharan Africa. Early independence is thus an indicator that colonies were able to organize resistance against the
} 
confirm that income has a negative effect in former colonies that became independent after 1900 (the reference) as compared to colonies that became independent before 1900 (for which the binary indicator takes value 1), for both fixed effects and GMM regressions.

As a final proxy for colonial history, one might expect that countries that have been subject to the rule of the late colonial powers should exhibit more extractive institutions. In view of the discussion in the introduction, one would expect that the window of opportunity hypothesis (with a negative income effect on democracy) should be more likely to apply to these countries. The analysis is therefore conducted by accounting for the main colonial powers of the late colonization era, the U.K., France and Belgium 33 The results in columns (9) to (12) show that the effect of income on democracy is (more) negative for countries that were ruled by the late colonizing powers that participated in the imperialist wave of colonization while the effect of income on democracy is insignificant for the colonies that were under the rule of the early colonizers ${ }^{34}$

\subsection{Robustness of the Results}

The results so far have documented a significant heterogeneity in the effect of income on democracy, both across former colonies and non-colonies, and within the sample of former colonies, depending on their institutions and colonial history. The results are compatible with the hypothesis that the effect of income on democracy is heterogenous depending on these country specific features. In particular, countries with relatively more extractive institutions, measured using available proxies, exhibit significantly smaller (or more negative) effects of income on democracy than countries with relatively more inclusive institutions.

The estimated heterogeneous effects of income on democracy also appear sizable quantitatively. For instance, for the sample of non-colonies, the income coefficient in Tables 1, 2 and 3 ranges from 0.08 to 0.21 in the five-year panels, and from around 0.19 to 0.5 in the ten-year panels ${ }^{35}$ In order to interpret these magnitudes, notice that these effects correspond to the change in the democracy colonizing power, as well as organize their own administration.

${ }^{33}$ As discussed below in more detail, these were the main powers behind the second wave of colonization after 1880, which was driven predominantly by "imperialist" motives to ensure access to resources (mainly in Africa), rather than "mercantilist" motives as in the era before 1880, see Olsson (2009). Due to the fact that the CEPII data contain information on the last colonizing power before independence, these powers indirectly also reflect other colonizing powers from the second wave, such as Germany.

${ }^{34}$ The results for similar proxies of colonial histories and institutions are discussed below.

${ }^{35}$ The corresponding ranges of the long-term effects are from 0.12 to 0.45 and from 0.18 to 0.6 , respectively, in the five-year and 10-year panels. 
index (which ranges from 0 to 1 ) that corresponds to a log-difference in income of 1 . The average increase in log income per capita in the sample of non-colonies over the sample period 1960 to 2000 was approximately $1.2^{36}$. The variability across non-colonies at a given point in time (e.g., in 1960 or 2000) exceeded 3. Therefore, the observed changes in income are compatible with substantial changes in democracy ${ }^{37}$ The corresponding magnitudes of the short-term effect for colonies are also sizable and range from -0.06 to -0.14 and -0.09 to -0.15 , respectively, for the five-year and ten-year panels.

The results are robust to the use of different measures for democracy, coding of colonies, proxies for institutions and colonial history, income data, to the use of alternative estimation methods, the inclusion of additional controls and consistently emerge in different samples of countries. This section briefly discusses the robustness of the results in these different dimensions. The respective estimation results are presented in Tables 4 to 17 in the Appendix that contains the Additional Material.

Alternative measures of democracy: Polity IV. Table 4 provides a summary of the results obtained when replicating the analysis of sections 3.2 and 3.3 with the alternative Polity IV measure of democracy used by AJRY (2008). The table contains the results for the different panel frequencies (five-year and ten-year data), and estimation techniques (OLS, GMM, IV and GMM-IV). The results are qualitatively identical and quantitatively very similar to the baseline results obtained with the Freedom House index 38

Alternative colony coding and samples. The results are robust to the use of alternative codings of colonial history, and for different samples. In particular, the results are confirmed, with the heterogenous effect of income in colonies and within colonies being slightly stronger, when using the coding of colonies from AJRY (2008) (which contain information for a smaller number of countries) and from Quality of Governance data set (which classifies Western offshoots as non-colonies). The respective results for the partially interacted model (2) can be found in Table 5. The results for estimates of model (1) on the different samples can be found in Tables 6 and 7.

\footnotetext{
${ }^{36}$ This corresponds to an increase in absolute income per capita of more than $200 \%$.

${ }^{37}$ The effects obtained with GMM and IV are even larger.

${ }^{38}$ The estimates are conducted using the same Polity-IV data as in AJRY (2008), which has a smaller number of observations and exhibits less variation compared to the preferred data from the Freedom House. The results are confirmed. The heterogeneity is slightly larger and statistically more significant when using the 2010 release of Polity data, which retains more observations. To avoid duplication, the corresponding results are made available upon request.
} 
Alternative income data, censoring and binary measures of democracy. Benhabib, Corvalan, and Spiegel (2011) and Corvalan (2011) suggest that the insignificant effect of income on democracy might depend on the specific choice of income and democracy variables and on the estimation procedure. A linear estimation model might deliver misleading estimates since the distribution of the democracy measure tends to be bi-modal and is censored. In addition, the use of the more recent releases of income data (like the PWT 7.1) allows to recover information for several countries and years (within countries) and offers the opportunity to test for heterogeneous income effects in a more general setting ${ }^{39}$ Another potential concern is about the use of a continuous rather than a binary measure of democracy: 40 A summary of the replication of the results using income data from PWT 7.1, for estimation methods that account for censoring of the democracy data, or for binary measures of democracy can be found in Tables 8,9 and 10, respectively. The results confirm the finding of a heterogenous significant effect of income depending on whether a country was subject to foreign rule, as well as within the sample of colonies depending on their colonial history and institutions 41

Heterogeneity with respect to the quality of democratic institutions. AJRY (2009) consider the possibility of a heterogeneous effect of income on democracy, depending on whether a country starts with a low level of democracy or a high level of democracy ${ }^{42}$ The empirical strategy involves using a binary indicator variable that equals 1 if a country has a lagged level of democracy below the sample mean, which is interacted with lagged income and captures the possibility of income promoting democracy. Likewise, a binary indicator that equals 1 if a country has a lagged level of

\footnotetext{
${ }^{39}$ One relevant caveat is, however, that most of the additional data that is not contained in the PWT 6.1, and thus not used by AJRY (2008), refers to former socialist countries for which data quality on GDP per capita might be questionable. In addition, the latest release adds countries located in the Middle East as well as smaller countries and islands.

${ }^{40}$ Several researchers have proposed use of binary, or discrete, measures of democracy instead of a continuous index. See in particular, Przeworski et al. (2000), Epstein et al. (2006), Cheibub, Gandhi, and Vreeland (2010) and Benhabib, Corvalan, and Spiegel (2011). To test the robustness of the results we use data from Cheibub, Gandhi, and Vreeland (2010) that is available at https://netfiles.uiuc.edu/cheibub/www/datasets.html. A caveat of relying on binary measures relates to the further reduction in period-to-period variability of democracy within countries overtime that can reduce the ability of the empirical model with country and time fixed effects to detect significant effects in the different sub-samples.

${ }^{41}$ Additional unreported results also suggest that the heterogeneity in the effect of income on democracy is more pronounced when censored observations are simply dropped from the sample or when using a logit estimator.

${ }^{42}$ The hypothesis behind this analysis is that income might have different effects for transitions to and away from democracy, based on evidence by Przeworski and Limongi (1997) and Przeworski et al. (2000).
} 
democracy above the sample mean interacted with lagged income captures the potentially different effect of income preventing coups and anti-democratic developments. The findings, reported in Table 11 suggest that this distinction leaves the results essentially unaffected. There is no evidence for different effects of income depending on the quality of democratic institutions in the previous period while the different income effect across colonies and non-colonies is confirmed.

Alternative proxies for institutional quality within colonies. The literature has used alternative proxies for colonial history and institutional quality. The share of population with European descent is sometimes considered to be related to better institutions because of long-run oriented settlement strategies of colonizers. The year of colonization captures the timing of colonization, which impacted heavily on the institutions set up in colonies. While early colonies, colonized before about 1880, were colonized mostly to expand the market for goods (the "mercantilist wave of colonization"), later colonization was driven mainly by exploitation and imperialist intentions (the "imperialist wave of colonization") which is likely to have led to more extractive institutions, see Olsson (2009). Finally, the religious fractionalization of a country has been argued to reflect the potential for, or prevalence of, divide-and-rule strategies that increase the extractive capacity of the colonizer, see Acemoglu and Robinson (2006). The results for these variables, shown in Table 12 . confirm the findings of substantial heterogeneity in the effect of income on democracy in colonies with different colonization history and institutional background.

Additional interactions. The finding of a heterogenous effect of income on democracy is also extended to the consideration of other country-specific characteristics that might be relevant for comparative development but, in view of the literature, should not be regarded per se as relevant proxies for broad-based institutions that emerged during the colonial history. These characteristics include the share of a country's land located in the tropics, the share of arable land, and whether a country is located in Africa. As illustrated by the findings reported in Table 13 , the main results are robust to the consideration of these further interactions, none of which has a significant effect on democracy: ${ }^{43}$

Dropping particular groups of countries in the sample. As discussed above, the baseline findings consistently emerge in different samples and with different income data. We have also checked whether the results are driven by countries whose information on income or democracy (or both)

\footnotetext{
${ }^{43}$ In line with AJRY, additional unreported results also deliver no systematic pattern of heterogeneity when splitting the sample by time-variant variables, such as income or education.
} 
might be deemed not fully reliable or by particular groups of countries. Tables 14 and 15 document that the results consistently emerge also when dropping countries in the former socialist block as well as by excluding countries in the Middle-East, countries that are predominantly inhabited by Muslims, or that are major oil exporter (belonging to the OPEC) ${ }^{44}$

Additional controls. The significant heterogeneity in the income effect is robust to the inclusion of additional controls like average school years, log of total population (in thousands), the median age in the population as well as labor share of gross value added, see Table 16 and $17{ }^{45}$ The results reveal that the estimate of the negative income effect is less precise for former colonies, but one has to keep in mind that the sample is reduced due to missing information on some of the controls. Within colonies, the heterogeneity is robust with respect to the inclusion of additional controls, with a significantly negative income effect for colonies with extractive early institutions.

\footnotetext{
${ }^{44}$ Major oil exporters include current and former OPEC members and data on socialist countries is taken from AJRY (2008). The classification of Middle-East countries is based in the CIA World Factbook. The share of the muslim population is taken from the Pew Research Center and countries with a share higher than $80 \%$ are excluded.

${ }^{45}$ The data are taken from AJRY (2008).
} 


\section{References}

Acemoglu, D., S. Johnson, And J. A. Robinson (2001): "The Colonial Origins of Comparative Development: An Empirical Investigation," American Economic Review, Vol. 91, No. 5, 1369-1401.

(2002): "Reversal of Fortune: Geography and Institutions in the Making of the Modern World Income Distribution," Quarterly Journal of Economics, Vol. 177, No. 4, 1231-1294.

Acemoglu, D., S. Johnson, J. A. Robinson, And P. Yared (2008): "Income and Democracy," American Economic Review, Vol. 98, No. 3, 808-842.

(2009): "Reevaluating the Modernization Hypothesis," Journal of Monetary Economics, Vol. 56, 1043-1058.

Acemoglu, D., And J. A. Robinson (2006): Economic Origins of Dictatorship and Democracy. Cambridge University Press.

(2012): Why Nations Fail: The Origins of Power, Prosperity, and Poverty. Crown Business, Random House, New York.

Alesina, A., A. Devleeschauwer, W. Easterly, S. Kurlat, and R. Wacziarg (2003): "Fractionalization," Journal of Economic Growth, pp. 155-194.

Arat, Z. F. (1988): "Democracy and Economic Development: Modernization Theory Revisited," Comparative Politics, Vol. 21, No. 1, 21-36.

Arellano, M., And S. Bond (1991): "Some Tests of Specification for Panel Data: Monte Carlo Evidence and an Application to Employment Equations," Review of Economic Studies, 58(2), $277-297$.

Arellano, M., And O. Bover (1995): "Another Look at the Instrumental Variable Estimation of Error-Component Models," Journal of Econometrics, 68(1), 29-51.

Ashraf, Q., And O. Galor (2011): "Dynamics and Stagnation in the Malthusian Epoch," American Economic Review, 101(5), 2003-2041.

Barro, R. J. (1999): "Determinants of Democracy," Journal of Political Economy, Vol. 107, No. $6,158-183$.

(2012): "Convergence and Modernization Revisited," mimeo, Harvard University.

Benhabib, J., A. Corvalan, and M. M. Spiegel (2011): "Reestablishing the Income-Democracy Nexus," Federal Reserve Bank of San Francisco, Working Paper 2011-09.

Bernhard, M., C. Reenock, and T. Nordstrom (2004): "The Legacy of Western Overseas Colonialism on Democratic Survival," International Studies Quarterly, Vol. 48, 225-250.

Bertocchi, G., and A. Guerzoni (2010): "Growth, History, or Institutions? What Explains State Fragility in Sub-Saharan Africa," CEPR Discussion Paper No. 8406.

Blundell, R., And S. Bond (1998): "Initial conditions and moment restrictions in dynamic panel data models," Journal of Econometrics, 87(1), 115 - 143.

Boix, C., And S. C. Stokes (2003): "Endogenous Democratization," World Politics, Vol. 55, No. $4,517-549$. 
Bollen, K. A., and R. W. Jackman (1985): "Political Democracy and the Size Distribution of Income," American Sociological Review, Vol. 50, 438-457.

Brown, J. M. (1999): "Epilogue," in The Oxford History of the British Empire, ed. by J. M. Brown, and W. R. Louis, vol. IV, pp. 703-711. Oxford University Press, Oxford.

Bruno, G. S. F. (2005): "Estimation and inference in dynamic unbalanced panel-data models with a small number of individuals," Stata Journal, 5(4), 473-500.

Burkhart, R. E., and M. S. Lewis-Beck (1994): "Comparative Democracy: The Economic Development Thesis," American Political Science Review, Vol. 88, No. 4, 903-910.

Cheibub, J. A., J. Gandhi, and J. R. VReeland (2010): "Democracy and Dictatorship Revisited," Public Choice, Vol. 143, 67-101.

Cheibub, J. A., and J. R. Vreeland (2010): "Economic Development and Democratization," in Dynamics of Democratization, ed. by N. Brown. Johns Hopkins University Press.

Corvalan, A. (2011): "On the Effect of Income on Democracy during the Postwar Period," Mimeo, NYU.

Diamond, L. (1992): "Economic Development and Democracy Reconsidered," in Reexamining Democracy, ed. by G. Marks, and L. Diamond. Sage Publications, London.

Epstein, D. L., R. Bates, J. Goldstone, I. Kristensen, and S. O'Halloran (2006): "Democratic Transitions," American Journal of Political Science, Vol. 50, No. 3, 551-569.

Glaeser, E., R. LaPorta, F. Lopez-de Silanes, and A. Shleifer (2004): "Do Institutions Cause Growth?," Journal of Economic Growth, 9(3), 271-303.

Huntington, S. P. (1991): The Third Wave. Democratization in the late Twentieth Century. University of Oklahoma Press, Norman.

Lipset, S. M. (1959): "Some Social Requisites of Democracy: Economic Development and Political Legitimacy," American Political Science Review, Vol. 53, No. 1, 69-105.

Lipset, S. M., K.-R. Seong, And J. C. Torres (1993): "A Comparative Analysis of the Social Requisites of Democracy," International Social Science Journal, Vol. 45, 155-175.

Nickell, S. (1981): "Biases in Dynamic Models with Fixed Effects," Econometrica, 49(6), 14171426.

Olsson, O. (2009): "On the Institutional Legacy of Mercantilist and Imperialist Colonialism," Journal of Comparative Economics, 37(4), 534-551.

Przeworski, A., M. E. Alvarez, J. A. Cheibub, and F. Limongi (2000): Democracy and Development. Political Institutions and Well-Being in the World, 1950-1990. Cambridge University Press.

Przeworski, A., And F. Limongi (1997): "Modernization: Theories and Facts," World Politics, 49, 155-183.

Putterman, L., And D. Weil (2010): "Post-1500 Population Flows and the Long-Run Determinants of Economic Growth and Inequality," Quarterly Journal of Economics, 125(4), 1627-1682. 
Roodman, D. (2009): "A Note on the Theme of Too Many Instruments," Oxford Bulletin of Economics and Statistics, 71(1), 135-158.

(2009b): "How to do xtabond2: An introduction to difference and system GMM in Stata," Stata Journal, 9(1), 86-136.

Rueschemeyer, D., E. Huber Stephens, and J. D. Stephens (1992): Capitalist Development and Democracy. University of Chicago Press, Chicago. 
Table 1: Replication and Baseline Results of the Effect of Income on Democracy

\begin{tabular}{|c|c|c|c|c|}
\hline \multirow[t]{3}{*}{ Dependent Variable } & \multicolumn{4}{|c|}{ Democracy (Freedom House) } \\
\hline & \multicolumn{2}{|c|}{5 -years } & \multicolumn{2}{|c|}{ 10-years } \\
\hline & (1) & $(2)$ & (3) & (4) \\
\hline Democracy $_{t-1}$ & $\begin{array}{c}0.379 * * * \\
{[0.047]}\end{array}$ & $\begin{array}{c}0.363^{* * *} \\
{[0.044]}\end{array}$ & $\begin{array}{l}-0.025 \\
{[0.075]}\end{array}$ & $\begin{array}{l}-0.069 \\
{[0.065]}\end{array}$ \\
\hline Log GDP per Capita $t-1$ & $\begin{array}{c}0.010 \\
{[0.032]}\end{array}$ & $\begin{array}{c}0.080^{* *} \\
{[0.039]}\end{array}$ & $\begin{array}{c}0.053 \\
{[0.056]}\end{array}$ & $\begin{array}{c}0.190^{* * *} \\
{[0.070]}\end{array}$ \\
\hline Log GDP per Capita $t-1 \times$ Colony & & $\begin{array}{c}-0.118^{* * *} * \\
{[0.042]}\end{array}$ & & $\begin{array}{c}-0.247^{* * *} \\
{[0.067]}\end{array}$ \\
\hline Observations & 945 & 945 & 457 & 457 \\
\hline Countries & 150 & 150 & 127 & 127 \\
\hline Adj. $R^{2}$ & 0.234 & 0.242 & 0.110 & 0.153 \\
\hline
\end{tabular}

Fixed-effect panel regressions with clustered standard errors in brackets. ***, **,* indicate significance at 1-, 5-, and 10-percent level, respectively. All regressions include country fixed effects and time fixed effects. The results in column (1) replicate those in AJRY (2008), Table 2 Col. (2). Results in column (3) replicate those in AJRY (2008), Table 2 Col. (7). The colony coding follows the CEPII data set. 


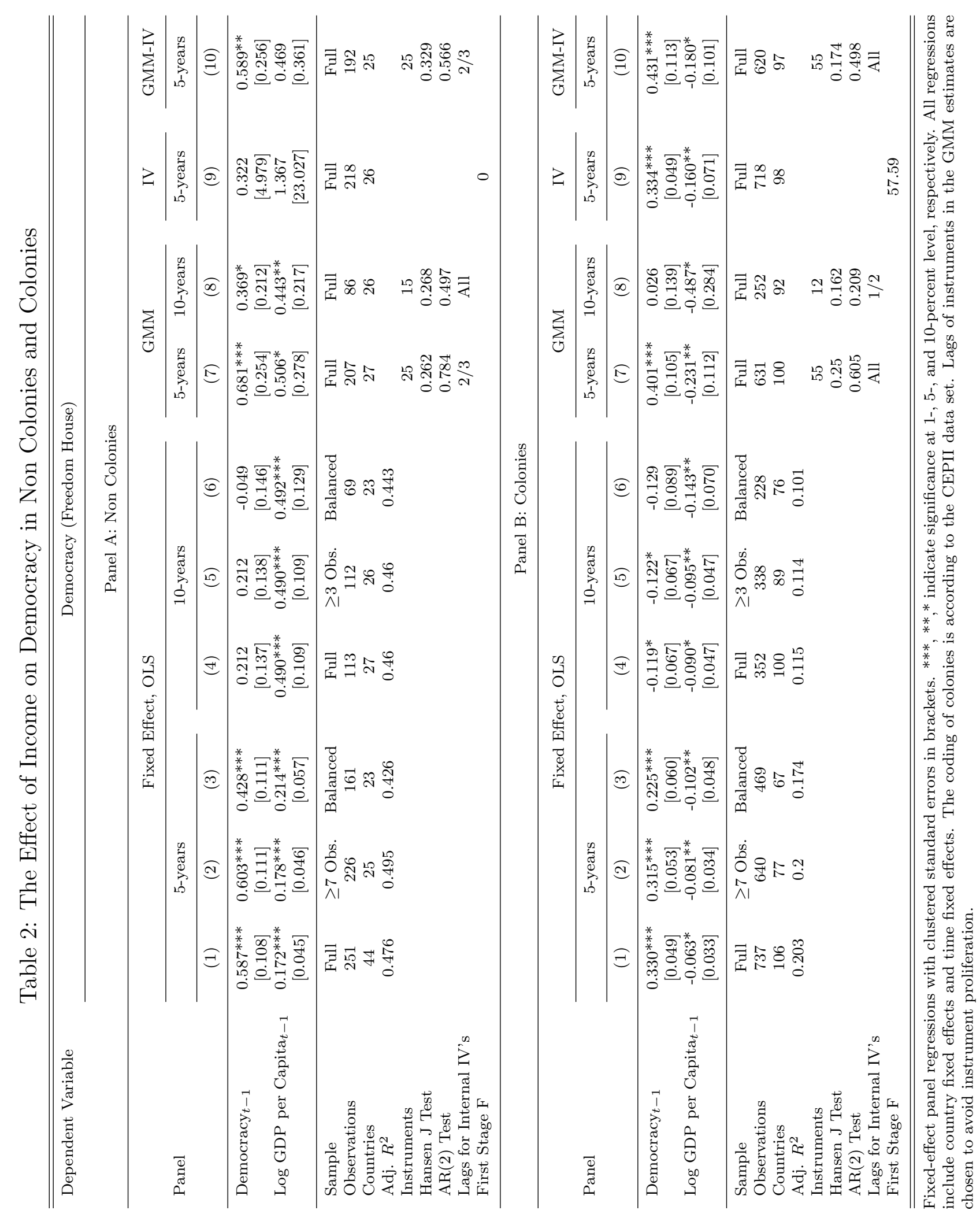




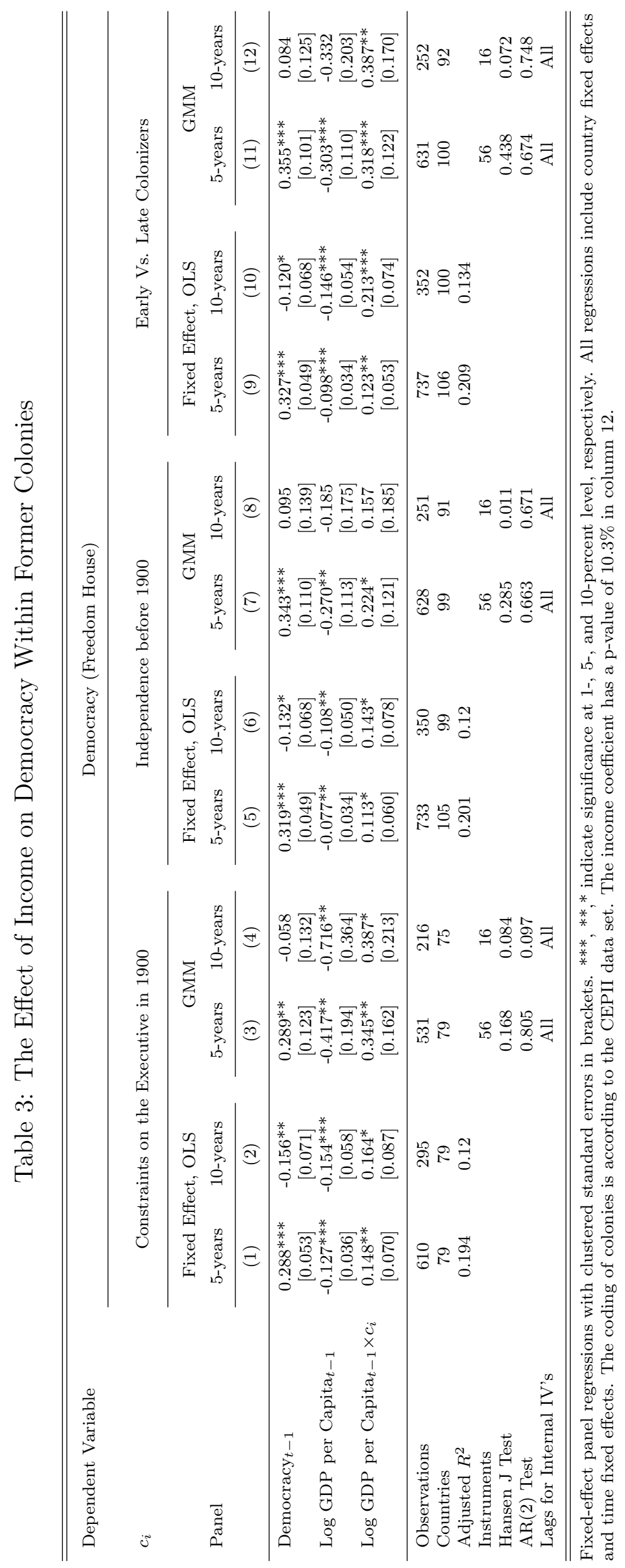




\section{Additional Material}

This appendix presents the results of the robustness checks that have been discussed in section 3.4. These results are reported for completeness and intended for potential publication as Online Supporting Material.

- Table 4: The Effect of Income on Democracy with the Polity IV Democracy Score. Robustness of the results in for non-colonies and colonies, and within the sample of colonies, respectively, using the Polity IV index of democratic quality.

- Table 5. Replication and Baseline Results of the Effect of Income on Democracy: Robustness. Robustness of the baseline results with respect to alternative colony codings and samples. The replication uses the coding by AJRY (2008) which includes information for fewer countries countries, and the coding by the Quality of Governance data, where Western offshots are coded as non colonies. Alternative samples apply the same sample restrictions as AJRY (2008) (Panel A), or relax these restrictions and exploit all available data points (Panel B).

- Table 6: The Effect of Income on Democracy: Alternative Codings of Colonies and Table77 The Effect of Income on Democracy Within Colonies: Alternative Codings of Colonies. Robustness of the results in for non-colonies and colonies, and within the sample of colonies, respectively. The replication uses the coding by AJRY (2008) which includes information for fewer countries countries, and the coding by the Quality of Governance data, where Western offshots are coded as non colonies.

- Table 8; The Effect of Alternative Income Data (PWT 7.1) on Democracy. Robustness of the results in for non-colonies and colonies, and within the sample of colonies, respectively. This table explores the robustness of the results with respect to the use of income data from PWT 7.1 (the most recent available release of the data). Compared to the PWT 6.1, the PWT 7.1 has data for a larger number of countries including, in particular, additional former socialist countries, countries in the Middle East, and some smaller countries and islands.

- Table 9. Tobit Estimates of the Effect of Income on Democracy. Robustness of the results in for non-colonies and colonies, and within the sample of colonies, respectively. Despite the incidental parameter problem the Tobit estimator is employed to account for censoring in the dependent variable (see Benhabib et al. (2011) and the discussion therein for details). 
- Table 10: The Effect of Income on Democracy: Binary Democracy Data. Robustness of the results in for non-colonies and colonies, and within the sample of colonies, respectively. Democracy is measured using a binary democracy score.

- Table 11: Heterogeneity with Respect to the Quality of Democratic Institutions. Robustness with respect to potential heterogeneity of the income effect for transitions to and transitions away from democracy, replicating the analysis in AJRY (2009), Table 2.

- Table 12: The Effect of Income and Democracy Within Colonies: Alternative Proxies for Colonial History and Institutions. Robustness with respect to the use of alternative proxies for institutional quality: share of population with European descent in 1970, colonization before/after 1880, and religious fractionalization.

- Table 13. Additional Interactions and the Effect of Income on Democracy. Robustness with respect to the inclusion of interactions between income and the share of land in the tropics, the percentage of arable land and an Africa dummy.

- Table 14: Income and Democracy in Non Colonies and Colonies: Different Samples and Table 15. Income and Democracy within Colonies: Different Samples. Replication of the results for non-colonies and colonies, and within the sample of colonies, respectively. Estimates are based on different samples which iteratively exclude former Socialist, Middle-East, Muslim and Opec countries.

- Table 16, Income and Democracy in Non Colonies and Colonies: Further Controls and Table 17: Income and Democracy within Colonies: Further Controls. Robustness of the results in for non-colonies and colonies, and within the sample of colonies, respectively. Inclusion of further controls in terms of $(\log )$ population, median age of the population, education and the labor share. 


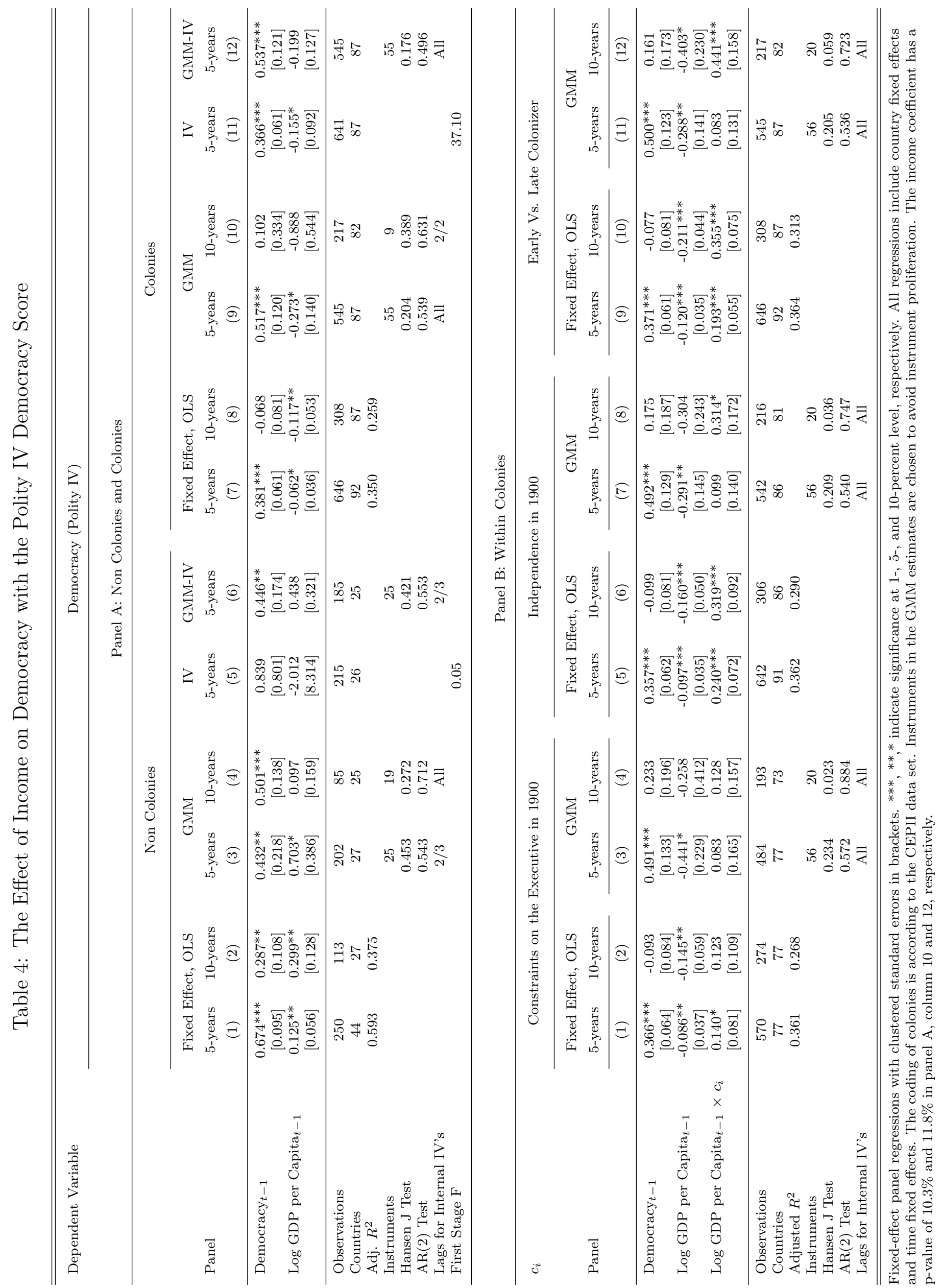


Table 5: Replication and Baseline Results of the Effect of Income on Democracy: Robustness

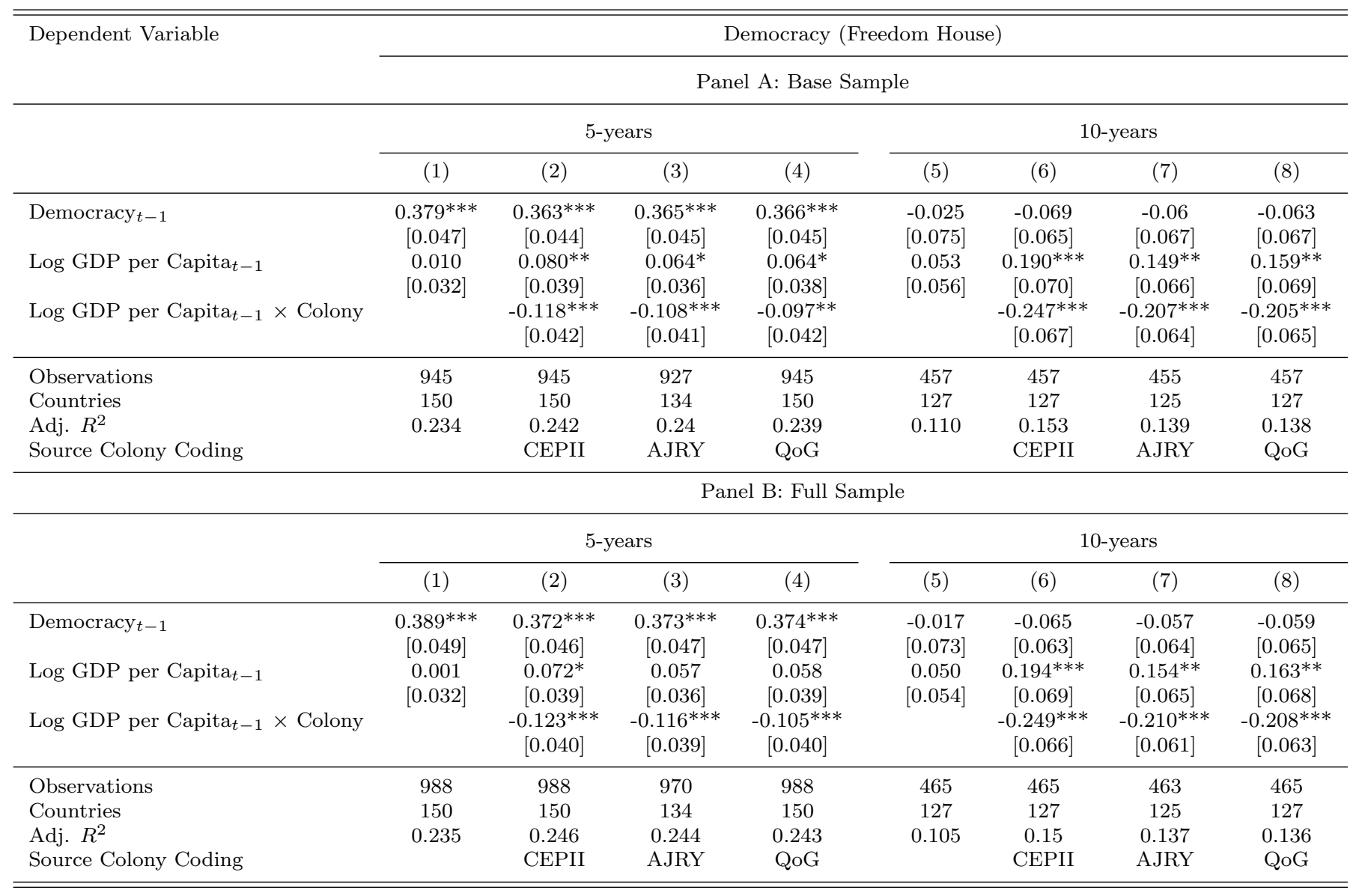

Fixed-effect panel regressions with clustered standard errors in brackets. ***, **** indicate significance at 1-, 5-, and 10-percent level, respectively. All regressions include country fixed effects and time fixed effects. The results in column (1) of panel A replicate those in AJRY (2008), Table 2 Col. (2). Results in column (5) of panel A replicate those in AJRY (2008), Table 2 Col. (7). 


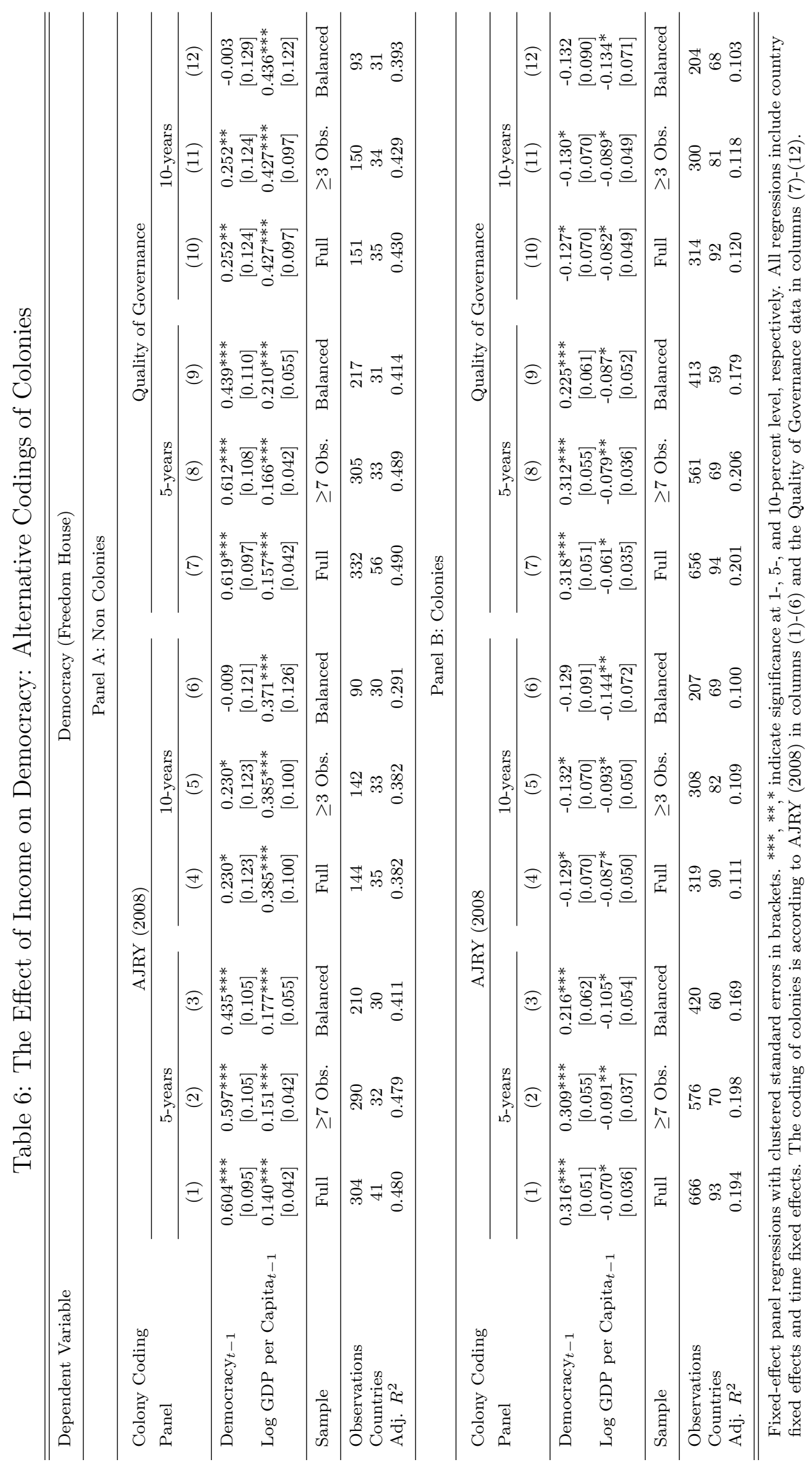




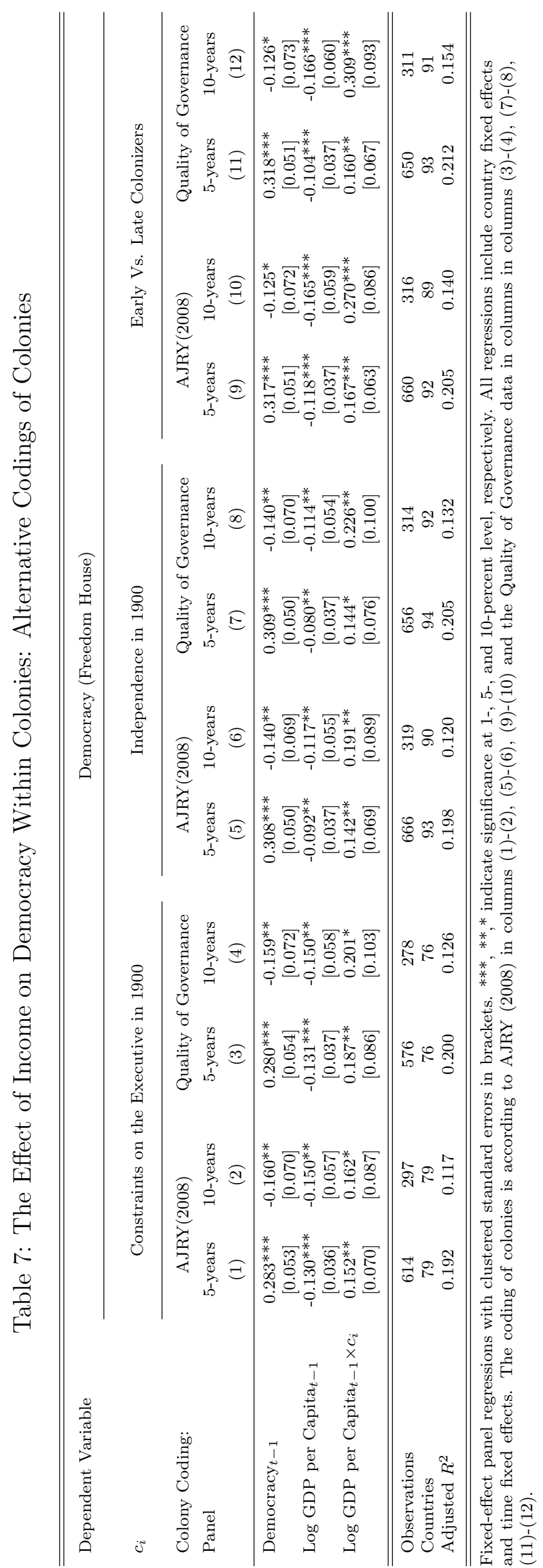


Table 8: The Effect of Alternative Income Data (PWT 7.1) on Democracy

\begin{tabular}{|c|c|c|c|c|c|c|c|c|}
\hline \multirow{4}{*}{$\begin{array}{l}\text { Dependent Variable } \\
\text { Sample } \\
\text { Panel }\end{array}$} & \multicolumn{8}{|c|}{ Democracy (Freedom House) } \\
\hline & \multicolumn{8}{|c|}{ Panel A: Non Colonies and Colonies } \\
\hline & \multicolumn{2}{|c|}{ Full } & \multicolumn{2}{|c|}{ Full } & \multicolumn{2}{|c|}{ Non-Colonies } & \multicolumn{2}{|c|}{ Colonies } \\
\hline & 5 -years & 10-years & $\begin{array}{l}\text { 5-years } \\
\text { (1) }\end{array}$ & $\begin{array}{l}\text { 10-years } \\
(2)\end{array}$ & $\begin{array}{c}\text { 5-years } \\
(3)\end{array}$ & $\begin{array}{c}\text { 10-years } \\
(4)\end{array}$ & $\begin{array}{l}\text { 5-years } \\
(5)\end{array}$ & $\begin{array}{c}\text { 10-years } \\
(6)\end{array}$ \\
\hline Democracy $_{t-1}$ & $\begin{array}{c}0.411^{* * *} \\
{[0.045]}\end{array}$ & $\begin{array}{c}0.033 \\
{[0.067]}\end{array}$ & $\begin{array}{c}0.397^{* * *} \\
{[0.043]}\end{array}$ & $\begin{array}{l}-0.004 \\
{[0.060]}\end{array}$ & $\begin{array}{c}0.628^{* * *} \\
{[0.086]}\end{array}$ & $\begin{array}{c}0.296^{* *} \\
{[0.119]}\end{array}$ & $\begin{array}{c}0.341^{* * *} \\
{[0.047]}\end{array}$ & $\begin{array}{l}-0.074 \\
{[0.067]}\end{array}$ \\
\hline $\begin{array}{l}\text { Log GDP per Capita } t-1 \\
\text { Log GDP per Capita } t-1 \times \text { Colony }\end{array}$ & $\begin{array}{l}-0.001 \\
{[0.027]}\end{array}$ & $\begin{array}{c}0.053 \\
{[0.047]}\end{array}$ & $\begin{array}{c}0.060^{*} \\
{[0.035]} \\
-0.107^{* * *} \\
{[0.037]}\end{array}$ & $\begin{array}{c}0.176 * * * \\
{[0.060]} \\
-0.213^{* * *} \\
{[0.061]}\end{array}$ & $\begin{array}{l}0.079^{*} \\
{[0.039]}\end{array}$ & $\begin{array}{c}0.273^{* * *} \\
{[0.083]}\end{array}$ & $\begin{array}{c}-0.053^{*} \\
{[0.029]}\end{array}$ & $\begin{array}{l}-0.056 \\
{[0.048]}\end{array}$ \\
\hline $\begin{array}{l}\text { Observations } \\
\text { Countries } \\
\text { Adj. } R^{2}\end{array}$ & $\begin{array}{c}1,153 \\
181 \\
0.246\end{array}$ & $\begin{array}{c}547 \\
157 \\
0.101\end{array}$ & $\begin{array}{c}1,153 \\
181 \\
0.254\end{array}$ & $\begin{array}{c}547 \\
157 \\
0.133\end{array}$ & $\begin{array}{c}302 \\
55 \\
0.478\end{array}$ & $\begin{array}{c}138 \\
36 \\
0.351\end{array}$ & $\begin{array}{c}851 \\
126 \\
0.196\end{array}$ & $\begin{array}{c}409 \\
121 \\
0.0868\end{array}$ \\
\hline Adj. $R^{2}$ & & & \multicolumn{6}{|c|}{ Panel B: Within Colonies } \\
\hline \multirow{2}{*}{$\begin{array}{l}c_{i} \\
\text { Panel }\end{array}$} & & & \multicolumn{2}{|c|}{ Execut. Constr. 1900} & \multicolumn{2}{|c|}{ Independence in 1900} & \multicolumn{2}{|c|}{ Early Colonizer } \\
\hline & & & $\begin{array}{l}\text { 5-years } \\
(1)\end{array}$ & $\begin{array}{l}\text { 10-years } \\
(2)\end{array}$ & $\begin{array}{l}\text { 5-years } \\
(3)\end{array}$ & $\begin{array}{c}\text { 10-years } \\
(4)\end{array}$ & $\begin{array}{l}\text { 5-years } \\
(5)\end{array}$ & $\begin{array}{c}\text { 10-years } \\
(6)\end{array}$ \\
\hline Democracy $_{t-1}$ & & & $\begin{array}{c}0.291^{* * *} \\
{[0.053]}\end{array}$ & $\begin{array}{c}-0.135^{*} \\
{[0.070]}\end{array}$ & $\begin{array}{c}0.320^{* * *} \\
{[0.046]}\end{array}$ & $\begin{array}{l}-0.103 \\
{[0.065]}\end{array}$ & $\begin{array}{c}0.339 * * * \\
{[0.046]}\end{array}$ & $\begin{array}{l}-0.076 \\
{[0.067]}\end{array}$ \\
\hline Log GDP per Capita $t-1$ & & & $\begin{array}{c}-0.101^{* *} \\
{[0.038]}\end{array}$ & $\begin{array}{c}-0.132^{* *} \\
{[0.062]}\end{array}$ & $\begin{array}{c}-0.071^{* *} \\
{[0.032]}\end{array}$ & $\begin{array}{l}-0.077 \\
{[0.052]}\end{array}$ & $\begin{array}{c}-0.066^{* *} \\
{[0.030]}\end{array}$ & $\begin{array}{r}-0.089^{*} \\
{[0.051]}\end{array}$ \\
\hline Log GDP per Capita $t-1 \times c_{i}$ & & & $\begin{array}{l}0.103^{*} \\
{[0.057]}\end{array}$ & $\begin{array}{c}0.138 \\
{[0.084]}\end{array}$ & $\begin{array}{c}0.100^{* *} \\
{[0.048]}\end{array}$ & $\begin{array}{c}0.140^{* *} \\
{[0.070]}\end{array}$ & $\begin{array}{c}0.065 \\
{[0.048]}\end{array}$ & $\begin{array}{c}0.157^{* *} \\
{[0.074]}\end{array}$ \\
\hline Observations & & & 649 & 315 & 845 & 406 & 851 & 409 \\
\hline Countries & & & 85 & 85 & 125 & 120 & 126 & 121 \\
\hline Adj. $R^{2}$ & & & 0.182 & 0.103 & 0.189 & 0.092 & 0.197 & 0.096 \\
\hline
\end{tabular}

Fixed-effect panel regressions with clustered standard errors in brackets. ***, *** indicate significance at 1-, 5-, and 10-percent level, respectively. All regressions include country fixed effects and time fixed effects. The coding of colonies is according to the CEPII data set. The income data is latest release of the Penn World Tables (version 7.1). 
Table 9: Tobit Estimates of the Effect of Income on Democracy

\begin{tabular}{|c|c|c|c|c|c|c|c|c|}
\hline \multirow{4}{*}{$\begin{array}{l}\text { Dependent Variable } \\
\text { Sample } \\
\text { Panel }\end{array}$} & \multicolumn{8}{|c|}{ Democracy (Freedom House) } \\
\hline & \multicolumn{8}{|c|}{ Panel A: Non Colonies and Colonies } \\
\hline & \multicolumn{2}{|c|}{ Full } & \multicolumn{2}{|c|}{ Full } & \multicolumn{2}{|c|}{ Non-Colonies } & \multicolumn{2}{|c|}{ Colonies } \\
\hline & $\begin{array}{l}\text { 5-years } \\
(1)\end{array}$ & $\begin{array}{c}\text { 10-years } \\
(2)\end{array}$ & $\begin{array}{c}\text { 5-years } \\
(3)\end{array}$ & $\begin{array}{c}\text { 10-years } \\
(4)\end{array}$ & $\begin{array}{l}\text { 5-years } \\
(5)\end{array}$ & $\begin{array}{l}\text { 10-years } \\
(6)\end{array}$ & $\begin{array}{l}\text { 5-years } \\
(7)\end{array}$ & $\begin{array}{c}\text { 10-years } \\
(8)\end{array}$ \\
\hline Democracy $_{t-1}$ & $\begin{array}{c}0.468^{* * *} \\
{[0.061]}\end{array}$ & $\begin{array}{c}0.003 \\
{[0.088]}\end{array}$ & $\begin{array}{c}0.439 * * * \\
{[0.057]}\end{array}$ & $\begin{array}{l}-0.089 \\
{[0.071]}\end{array}$ & $\begin{array}{c}0.663^{* * *} \\
{[0.002]}\end{array}$ & $\begin{array}{c}0.172 \\
{[0.164]}\end{array}$ & $\begin{array}{c}0.401^{* * *} \\
{[0.061]}\end{array}$ & $\begin{array}{l}-0.119 \\
{[0.079]}\end{array}$ \\
\hline $\begin{array}{l}\text { Log GDP per Capita } t-1 \\
\text { Log GDP per Capita } t-1 \times \text { Colony }\end{array}$ & $\begin{array}{c}0.051 \\
{[0.041]}\end{array}$ & $\begin{array}{c}0.111 \\
{[0.074]}\end{array}$ & $\begin{array}{c}0.174^{* * *} \\
{[0.052]} \\
-0.217^{* * *} \\
{[0.060]}\end{array}$ & $\begin{array}{c}0.447^{* * *} \\
{[0.103]} \\
-0.544^{* * *} \\
{[0.109]}\end{array}$ & $\begin{array}{c}0.147^{* * *} \\
{[0.000]}\end{array}$ & $\begin{array}{c}0.601^{* * * *} \\
{[0.158]}\end{array}$ & $\begin{array}{l}-0.032 \\
{[0.047]}\end{array}$ & $\begin{array}{l}-0.101 \\
{[0.066]}\end{array}$ \\
\hline $\begin{array}{l}\text { Observations } \\
\text { Countries } \\
\text { Pseudo } R^{2}\end{array}$ & $\begin{array}{c}988 \\
150 \\
0.903\end{array}$ & $\begin{array}{c}465 \\
127 \\
0.865\end{array}$ & $\begin{array}{c}980 \\
148 \\
0.916\end{array}$ & $\begin{array}{c}462 \\
126 \\
0.923\end{array}$ & $\begin{array}{c}251 \\
44 \\
1.014\end{array}$ & $\begin{array}{c}113 \\
27 \\
0.995\end{array}$ & $\begin{array}{c}737 \\
106 \\
0.884\end{array}$ & $\begin{array}{c}352 \\
100 \\
0.897\end{array}$ \\
\hline & & & \multicolumn{6}{|c|}{ Panel B: Within Colonies } \\
\hline$c_{i}$ & & & \multicolumn{2}{|c|}{ Execut. Constr. 1900} & \multicolumn{2}{|c|}{ Independence in 1900} & \multicolumn{2}{|c|}{ Early Colonizer } \\
\hline Panel & & & $\begin{array}{l}\text { 5-years } \\
(1)\end{array}$ & $\begin{array}{l}\text { 10-years } \\
(2)\end{array}$ & $\begin{array}{l}\text { 5-years } \\
(3)\end{array}$ & $\begin{array}{l}\text { 10-years } \\
(4)\end{array}$ & $\begin{array}{l}\text { 5-years } \\
(5)\end{array}$ & $\begin{array}{c}\text { 10-years } \\
\text { (6) }\end{array}$ \\
\hline Democracy $_{t-1}$ & & & $\begin{array}{c}0.332^{* * *} \\
{[0.064]}\end{array}$ & $\begin{array}{c}-0.169^{* *} \\
{[0.080]}\end{array}$ & $\begin{array}{c}0.381^{* * *} \\
{[0.061]}\end{array}$ & $\begin{array}{c}-0.142^{*} \\
{[0.079]}\end{array}$ & $\begin{array}{c}0.399^{* * *} \\
{[0.061]}\end{array}$ & $\begin{array}{l}-0.118 \\
{[0.080]}\end{array}$ \\
\hline Log GDP per Capitat-1 & & & $\begin{array}{c}-0.140 * * * \\
{[0.044]}\end{array}$ & $\begin{array}{c}-0.187^{* *} \\
{[0.073]}\end{array}$ & $\begin{array}{l}-0.056 \\
{[0.049]}\end{array}$ & $\begin{array}{c}-0.132^{*} \\
{[0.071]}\end{array}$ & $\begin{array}{l}-0.071 \\
{[0.048]}\end{array}$ & $\begin{array}{c}-0.161^{* * *} \\
{[0.076]}\end{array}$ \\
\hline Log GDP per Capita $t-1 \times c_{i}$ & & & $\begin{array}{c}0.227^{* *} \\
{[0.099]}\end{array}$ & $\begin{array}{l}0.245^{*} \\
{[0.127]}\end{array}$ & $\begin{array}{l}0.166^{*} \\
{[0.088]}\end{array}$ & $\begin{array}{l}0.215^{*} \\
{[0.122]}\end{array}$ & $\begin{array}{l}0.137^{*} \\
{[0.082]}\end{array}$ & $\begin{array}{c}0.258^{* *} \\
{[0.123]}\end{array}$ \\
\hline Observations & & & 610 & 295 & 733 & 350 & 737 & 352 \\
\hline Countries & & & 79 & 79 & 105 & 99 & 106 & 100 \\
\hline Pseudo $R^{2}$ & & & 0.887 & 0.903 & 0.891 & 0.903 & 0.887 & 0.908 \\
\hline
\end{tabular}

Two-sided tobit regressions with clustered standard errors in brackets. ***, ***, indicate significance at 1-, 5-, and 10-percent level, respectively. All regressions include country fixed effects and time fixed effects. The coding of colonies is according to the CEPII data set. The income coefficient has a p-value of $12.6 \%$ in panel A, column 8 . 


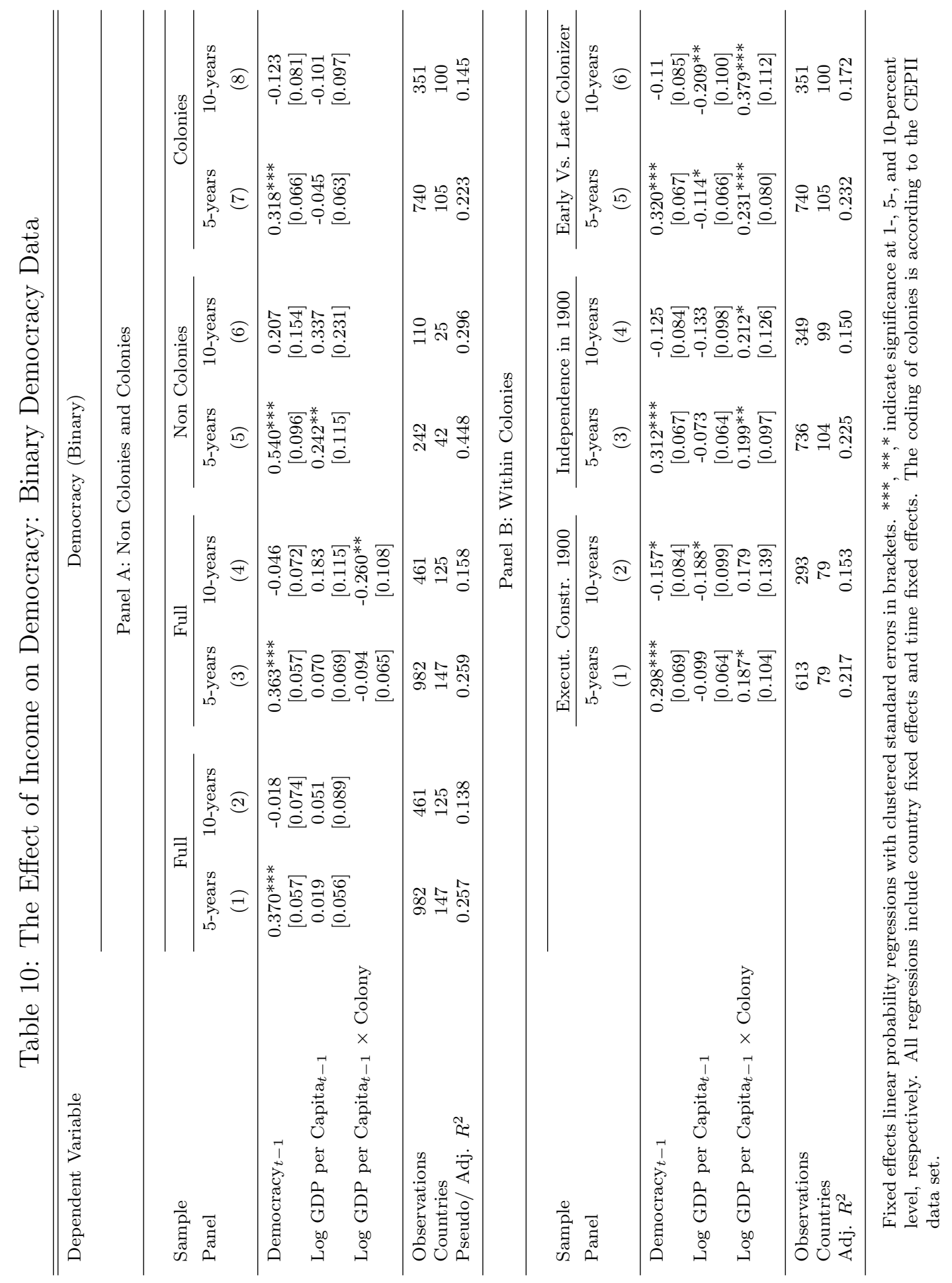




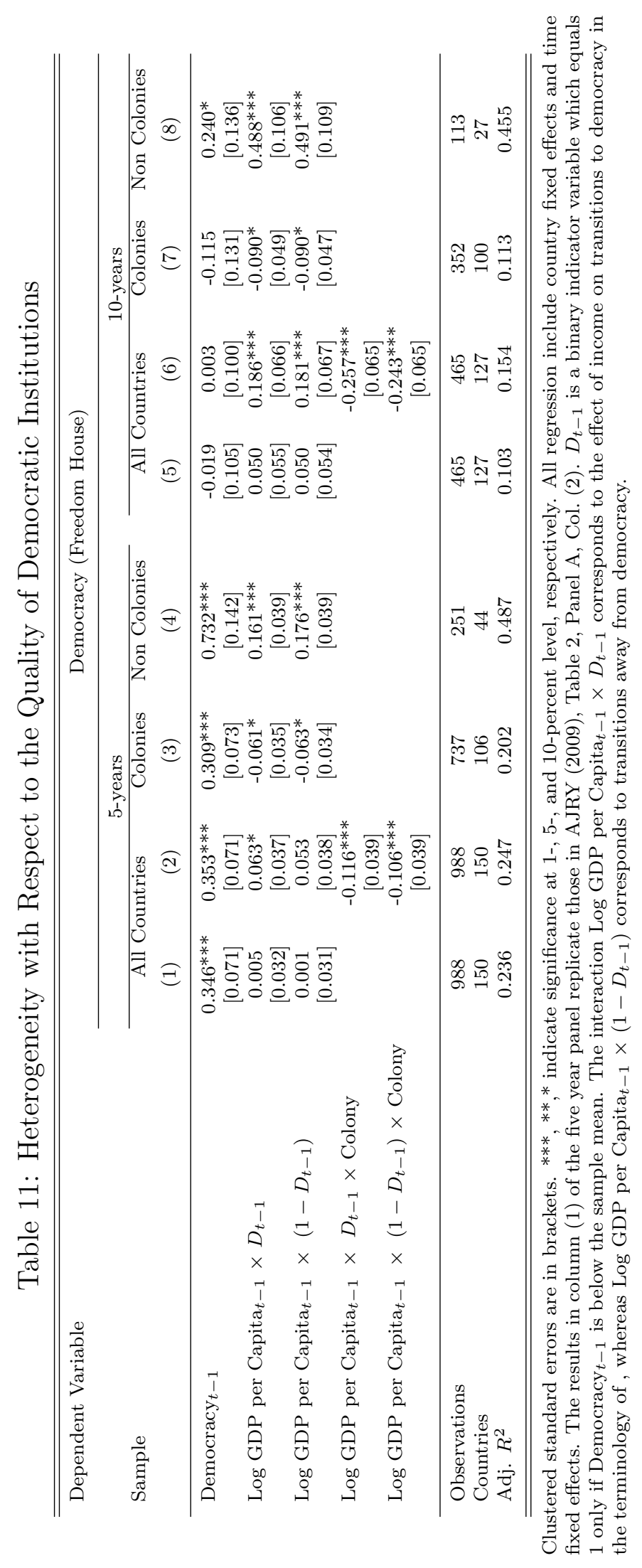




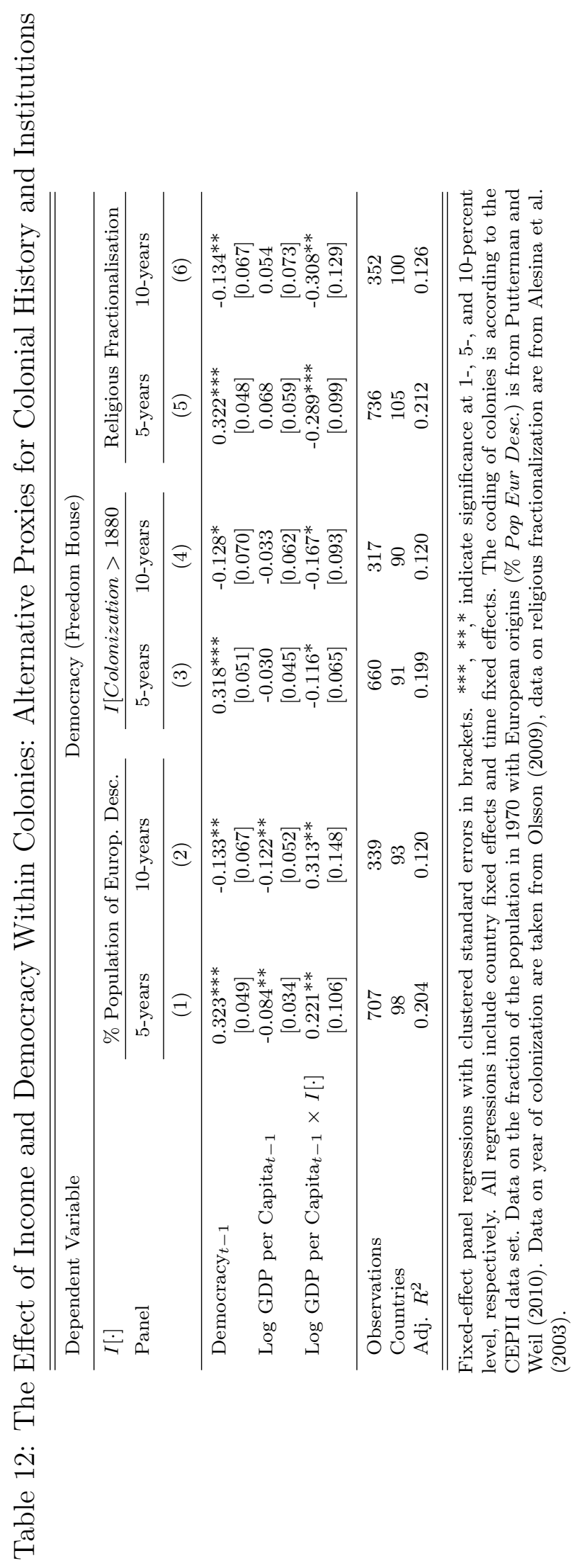


Table 13: Additional Interactions and the Effect of Income on Democracy

\begin{tabular}{|c|c|c|c|c|c|c|}
\hline \multirow{5}{*}{$\begin{array}{l}\text { Dependent Variable } \\
I[\cdot] \\
\text { Panel }\end{array}$} & \multicolumn{6}{|c|}{ Democracy (Freedom House) } \\
\hline & \multicolumn{6}{|c|}{ Panel A: Further Interactions in Full Sample } \\
\hline & \multicolumn{2}{|c|}{$\%$ Land in Tropics } & \multicolumn{2}{|c|}{$\%$ Arable Land } & \multicolumn{2}{|c|}{ Africa } \\
\hline & 5-years & 10-years & 5 -years & 10-years & 5 -years & 10-years \\
\hline & (1) & $(2)$ & (3) & (4) & (5) & (6) \\
\hline $\operatorname{Democracy}_{t-1}$ & $\begin{array}{c}0.361^{* * *} \\
{[0.049]}\end{array}$ & $\begin{array}{c}-0.09 \\
{[0.063]}\end{array}$ & $\begin{array}{c}0.369^{* * *} \\
{[0.046]}\end{array}$ & $\begin{array}{l}-0.067 \\
{[0.063]}\end{array}$ & $\begin{array}{c}0.372^{* * *} \\
{[0.046]}\end{array}$ & $\begin{array}{l}-0.066 \\
{[0.063]}\end{array}$ \\
\hline Log GDP per Capita $t-1$ & $\begin{array}{c}0.047 \\
{[0.043]}\end{array}$ & $\begin{array}{c}0.168^{* *} \\
{[0.075]}\end{array}$ & $\begin{array}{l}0.007 \\
{[0.047]}\end{array}$ & $\begin{array}{c}0.157^{* *} \\
{[0.072]}\end{array}$ & $\begin{array}{l}0.072^{*} \\
{[0.039]}\end{array}$ & $\begin{array}{c}0.197^{* * *} \\
{[0.070]}\end{array}$ \\
\hline Log GDP per Capita ${ }_{t-1} \times$ Colony & $\begin{array}{c}-0.136^{* * * *} \\
{[0.040]}\end{array}$ & $\begin{array}{c}-0.284^{* * *} \\
{[0.066]}\end{array}$ & $\begin{array}{c}-0.091^{* *} \\
{[0.042]}\end{array}$ & $\begin{array}{c}-0.228^{* * *} \\
{[0.069]}\end{array}$ & $\begin{array}{c}-0.122^{* * *} \\
{[0.041]}\end{array}$ & $\begin{array}{c}-0.239 * * * \\
{[0.070]}\end{array}$ \\
\hline Log GDP per Capita $t-1 \times I[\cdot]$ & $\begin{array}{c}0.035 \\
{[0.044]}\end{array}$ & $\begin{array}{c}0.088 \\
{[0.066]}\end{array}$ & $\begin{array}{c}0.018 \\
{[0.012]}\end{array}$ & $\begin{array}{c}0.009 \\
{[0.016]}\end{array}$ & $\begin{array}{l}-0.002 \\
{[0.054]}\end{array}$ & $\begin{array}{l}-0.034 \\
{[0.069]}\end{array}$ \\
\hline Observations & 912 & 431 & 970 & 457 & 988 & 465 \\
\hline Countries & 134 & 112 & 147 & 125 & 150 & 127 \\
\hline \multirow[t]{2}{*}{ Adj. $R^{2}$} & 0.236 & 0.154 & 0.237 & 0.139 & 0.245 & 0.148 \\
\hline & \multicolumn{6}{|c|}{ Panel B: Further Interactions Within Colonies } \\
\hline$I[\cdot]$ & \multicolumn{2}{|c|}{$\%$ Land in Tropics } & \multicolumn{2}{|c|}{$\%$ Arable Land } & \multicolumn{2}{|c|}{ Africa } \\
\hline \multirow[t]{2}{*}{ Panel } & 5 -years & 10-years & 5 -years & 10-years & 5 -years & 10-years \\
\hline & (1) & $(2)$ & $(3)$ & (4) & (5) & (6) \\
\hline $\operatorname{Democracy}_{t-1}$ & $\begin{array}{c}0.312^{* * *} \\
{[0.052]}\end{array}$ & $\begin{array}{c}-0.155^{* *} \\
{[0.065]}\end{array}$ & $\begin{array}{c}0.329 * * * \\
{[0.049]}\end{array}$ & $\begin{array}{l}-0.119^{*} \\
{[0.067]}\end{array}$ & $\begin{array}{c}0.330^{* * * *} \\
{[0.049]}\end{array}$ & $\begin{array}{c}-0.120^{*} \\
{[0.067]}\end{array}$ \\
\hline Log GDP per Capita $t-1$ & $\begin{array}{c}-0.080^{* *} \\
{[0.038]}\end{array}$ & $\begin{array}{c}-0.114^{* *} \\
{[0.053]}\end{array}$ & $\begin{array}{c}-0.071^{* *} \\
{[0.034]}\end{array}$ & $\begin{array}{l}-0.059 \\
{[0.045]}\end{array}$ & $\begin{array}{c}-0.069^{*} \\
{[0.038]}\end{array}$ & $\begin{array}{l}-0.088 \\
{[0.058]}\end{array}$ \\
\hline Log GDP per Capitat $-1 \times I[\cdot]$ & $\begin{array}{c}0.004 \\
{[0.049]}\end{array}$ & $\begin{array}{c}0.024 \\
{[0.067]}\end{array}$ & $\begin{array}{c}0.005 \\
{[0.011]}\end{array}$ & $\begin{array}{l}-0.021 \\
{[0.014]}\end{array}$ & $\begin{array}{c}0.013 \\
{[0.057]}\end{array}$ & $\begin{array}{l}-0.005 \\
{[0.071]}\end{array}$ \\
\hline Observations & 668 & 321 & 727 & 347 & 737 & 352 \\
\hline Countries & 91 & 86 & 105 & 99 & 106 & 100 \\
\hline Adj. $R^{2}$ & 0.197 & 0.128 & 0.201 & 0.114 & 0.202 & 0.113 \\
\hline
\end{tabular}

Fixed-effect panel regressions with clustered standard errors in brackets. $* * *, * *, *$ indicate significance at 1-, 5-, and 10-percent level, respectively. All regressions include country fixed effects and time fixed effects. The coding of colonies is according to the CEPII data set. Data on land in tropics, arable land and the Africa dummy is taken from Ashraf and Galor (2011). 


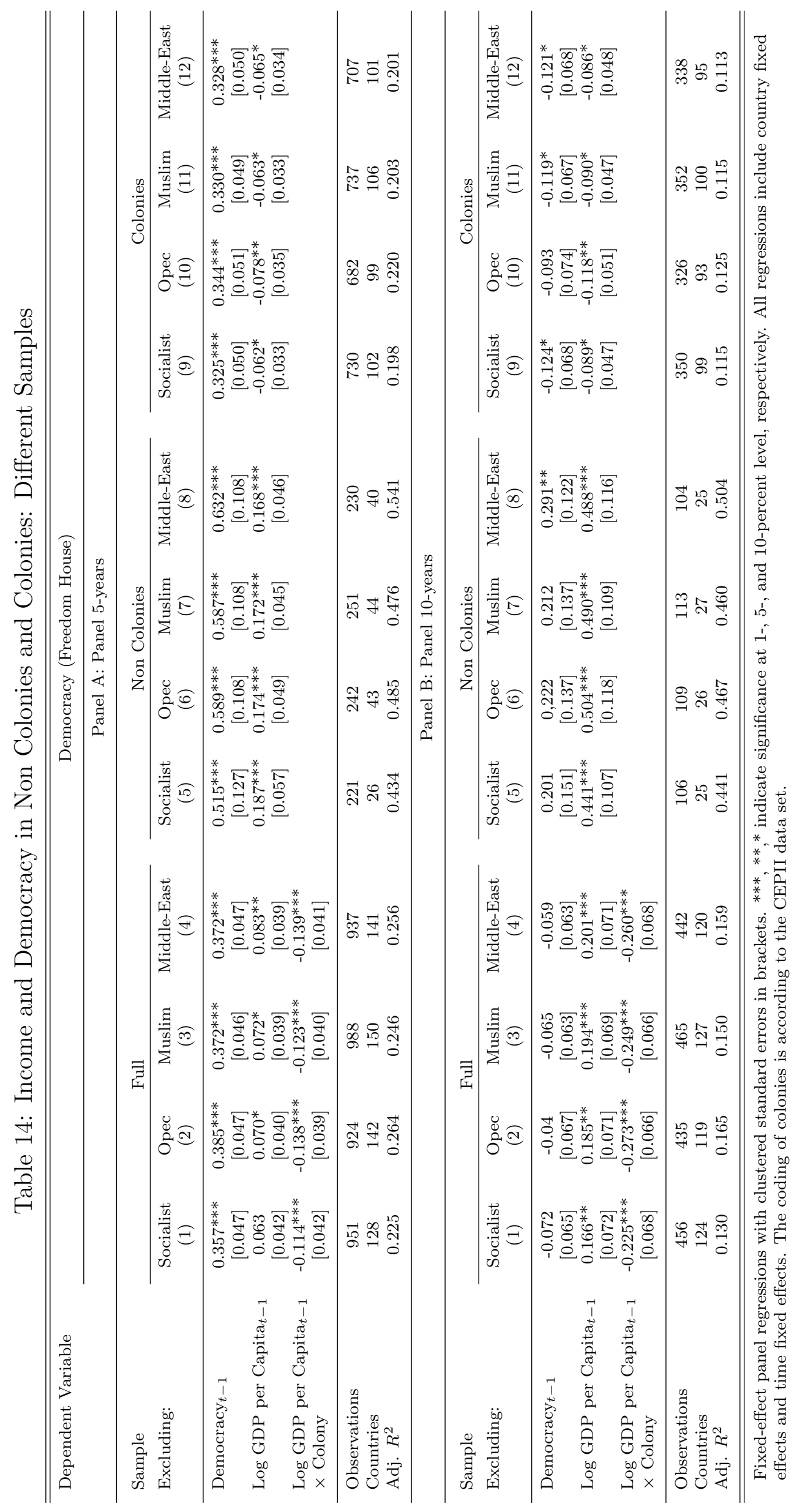




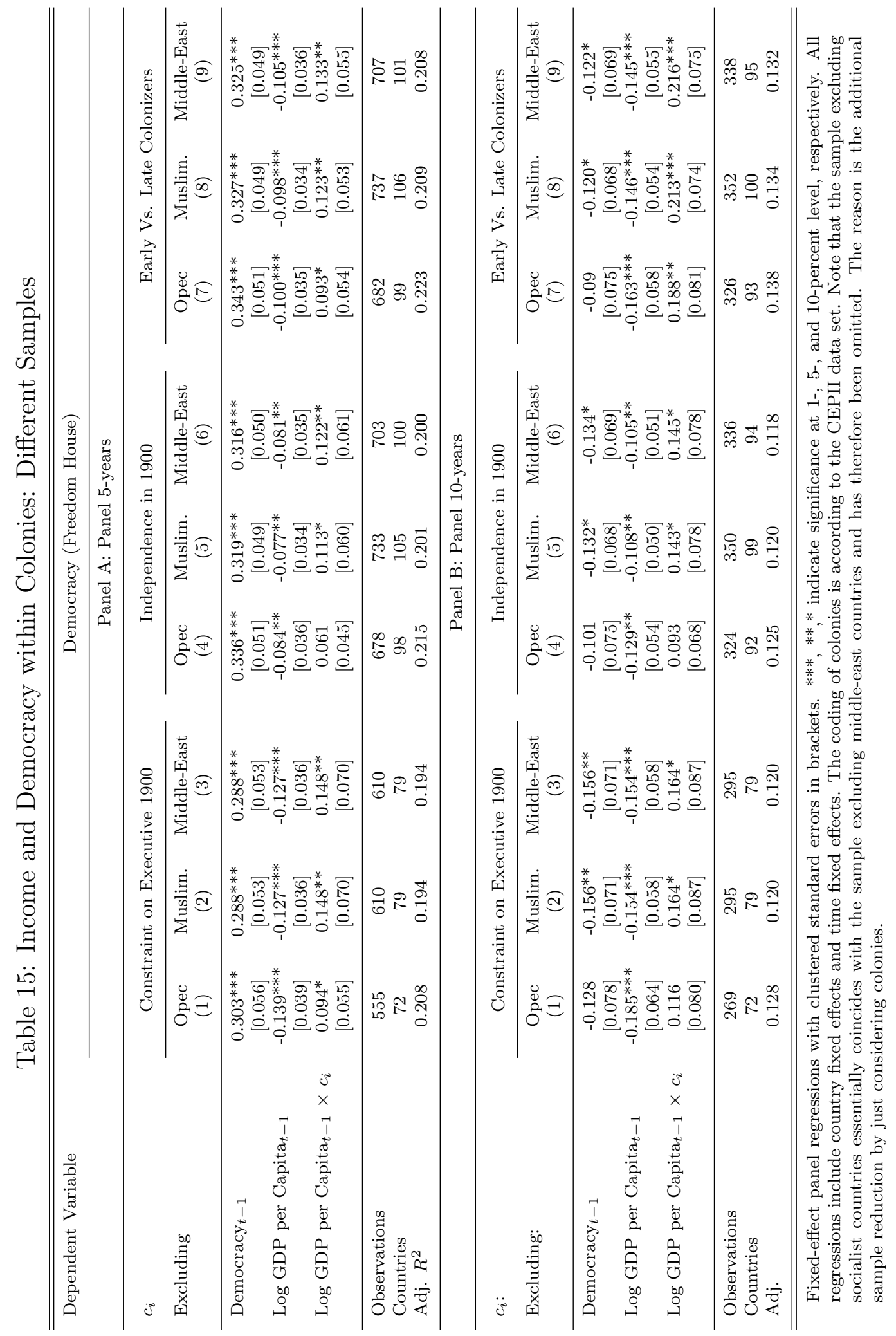




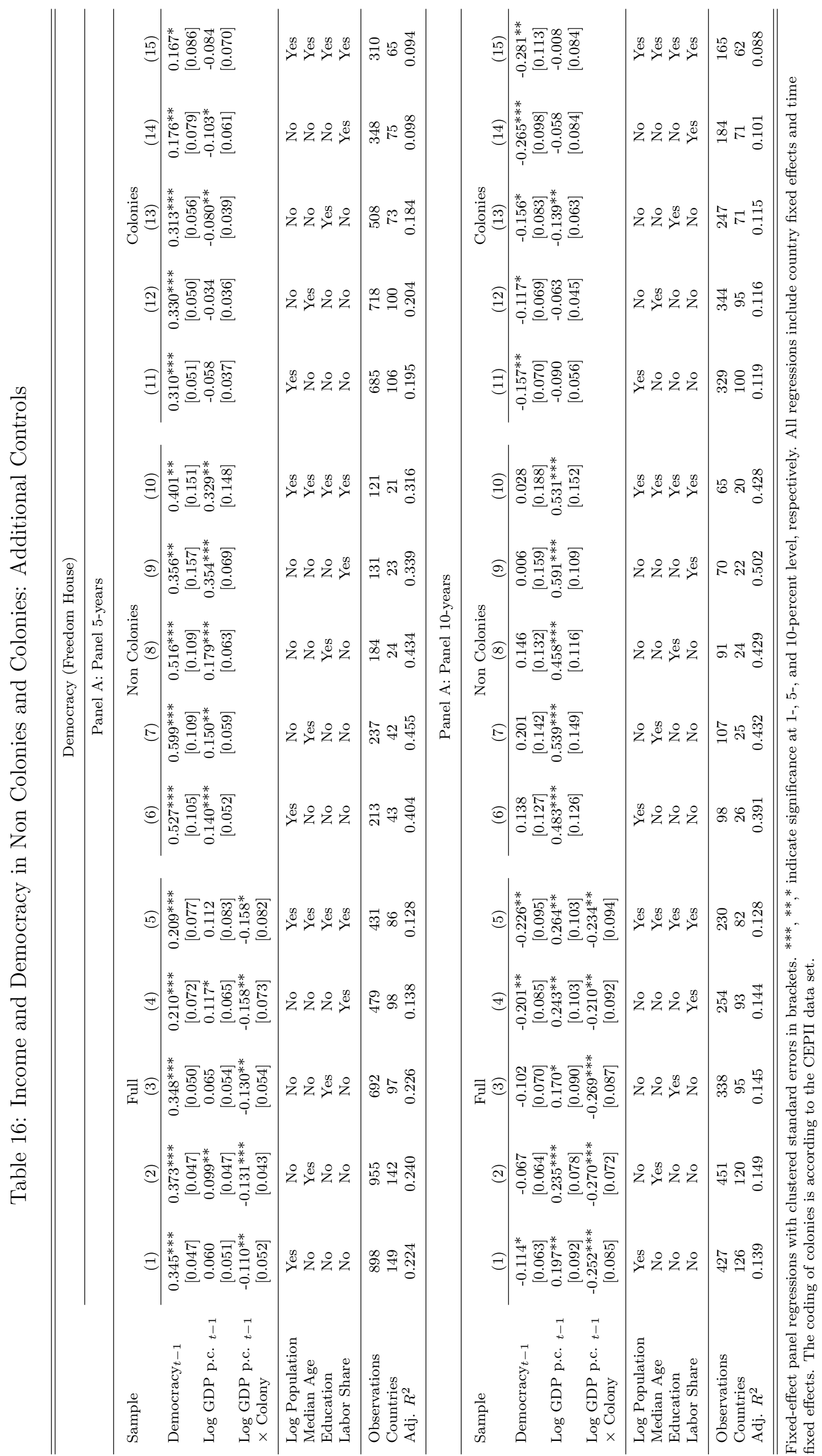


